\title{
Growth, Crystal Structure, Hirshfeld Surface Analysis, DFT Studies, Physicochemical Characterization And Cytotoxicity Assays of Novel Organic Triphosphate
}

\section{Yathreb Oueslati}

Carthage University, Faculty of Sciences of Bizerte

Sevgi Kansız

Samsun University

Necmi Dege

Ondokuz Mayıs University

Cristina de la Torre Paredes

Polytechnic University of Valencia

Antoni Llopis Lorente

Polytechnic University of Valencia

Ramón Martínez-Máñez

Polytechnic University of Valencia

wajda sta ( $\square$ wajda_sta@yahoo.fr)

Carthage University, Faculty of Sciences of Bizerte

\section{Research Article}

Keywords: Triphosphate, X-ray diffraction, Density functional theory, Hirshfeld surface, Spectroscopy, Cytotoxicity assays

Posted Date: September 7th, 2021

DOl: https://doi.org/10.21203/rs.3.rs-703211/v1

License: (9) This work is licensed under a Creative Commons Attribution 4.0 International License. Read Full License

Version of Record: A version of this preprint was published at Journal of Molecular Modeling on February 19th, 2022. See the published version at https://doi.org/10.1007/s00894-022-05047-5. 


\section{Growth, crystal structure, Hirshfeld surface analysis, DFT studies, physicochemical characterization and cytotoxicity assays of novel organic triphosphate}

Yathreb Oueslati ${ }^{1}$, Sevgi Kansız ${ }^{2}$, Necmi Dege ${ }^{3}$, Cristina de la Torre Paredes ${ }^{4}$, Antoni Llopis-Lorente ${ }^{4}$, Ramón Martínez-Máñez ${ }^{4}$, and Wajda Smirani Sta*,1

${ }^{1}$ Department of chemistry, Faculty of Sciences of Bizerte, Carthage University, 7021 Zarzouna, Tunisia Corresponding e-mail: wajda_sta@yahoo.fr

${ }^{2}$ Department of Fundamental Sciences, Faculty of Engineering, Samsun University, 55420, Samsun, Turkey

${ }^{3}$ Department of physics, Faculty of Arts and Sciences, Ondokuz Mayıs University, 55139, Samsun, Turkey

${ }^{4}$ Department of chemistry, Institute for Molecular Recognition and Technological Development (IDM), Polytechnic University of Valencia, Camino de Vera s/n, 46022, Valencia (Spain)

\section{Abstract}

A novel interesting organic-inorganic hybrid compound, named (1-phenylpiperazinium) trihydrogen triphosphate, with the formula $\left(\mathrm{C}_{10} \mathrm{H}_{15} \mathrm{~N}_{2}\right)_{2} \mathrm{H}_{3} \mathrm{P}_{3} \mathrm{O}_{10}$ has been obtained by low speed of evaporation at room temperature after using the ion exchange chemical procedure. To carry out a detailed crystallographic structure analysis, single-crystal X-ray diffraction has been reported. In the molecular arrangement, the different entities are held together through $\mathrm{N}-\mathrm{H} \cdots \mathrm{O}, \mathrm{O}-\mathrm{H} \cdots \mathrm{O}$ and $\mathrm{C}-\mathrm{H} \cdots \mathrm{O}$ hydrogen bonds, building up a three dimensional packing. Powder X-ray diffraction analysis is acquired to confirm the purity of the product. The nature and the proportion of intermolecular interactions were investigated by Hirshfeld surfaces analysis. In order to support the experimental results, a density functional theory (DFT) calculation were performed, using the Becke-3Parameter-Lee-Yang-Parr (B3LYP) function with LANL2DZ basis set, and the data indicate the much agreement between the experimental and the theoretical results. Thus, the physicochemical properties were studied employing a variety of techniques (FT-IR, NMR, UV-Visible and photoluminescence). To get an insight of the possible employment of the present material in biology, cell viability assays were performed.

Keywords Triphosphate• X-ray diffraction• Density functional theory• Hirshfeld surface• Spectroscopy• Cytotoxicity assays

\section{Introduction}

The scientific community has been focused more than ever in improvement and development of organicinorganic hybrid materials due to the growing need for new sophisticated products to allow the access to a various spectrum of functionalities [1-7]. These composites become trend thanks to their interesting features to gather the excellent merits of both organic and inorganic worlds on the molecular level. Up to date, hybrid solids are subject to many scientific studies due to their low cost, ease of synthesis, structural tenability and specific physical, chemical and biological properties. Such materials can be applied in both academic research and technological applications such as optic [8,9], electronic [10], mechanics, sensors, magnetism [11,12], catalysis and medicine [13,14].

In this context, the main focus was on the hybrid compounds based on phosphates, in particular. Among them, the choice was on the triphosphates, those with the formula of the anion $\left[\mathrm{P}_{3} \mathrm{O}_{10}\right]^{5-}$. Unsurprisingly, the number of these series of compounds remains limited in comparison with other condensed phosphates because they are chemically unstable in their synthesis. Indeed, the phosphoric chain containing three $\mathrm{PO}_{4}$ tetrahedra, which are linked together by two internal oxygen atoms, can be destructed and gives either a diphosphate or 
monophosphate compounds. Since their first synthesis, only eight composites have been appeared in literature. These include $\left(2-\mathrm{C}_{2} \mathrm{H}_{5} \mathrm{C}_{6} \mathrm{H}_{4} \mathrm{NH}_{3}\right)_{3} \mathrm{H}_{2} \mathrm{P}_{3} \mathrm{O}_{10}$ [15], $\left(\mathrm{C}_{4} \mathrm{~N}_{2} \mathrm{H}_{12}\right)_{2} \mathrm{HP}_{3} \mathrm{O}_{10}$. $\mathrm{H}_{2} \mathrm{O}$ [16], [ $\left.\left(\mathrm{CH}_{3} \mathrm{O}\right)_{2}\left(\mathrm{C}_{6} \mathrm{H}_{3} \mathrm{NH}_{3}\right)\right]_{3} \mathrm{H}_{2} \mathrm{P}_{3} \mathrm{O}_{10}$ [17], [4- $\left.\left(\mathrm{OCH}_{3}\right) \mathrm{C}_{6} \mathrm{H}_{4} \mathrm{CH}_{2} \mathrm{NH}_{3}\right]_{4} \mathrm{H}_{2} \mathrm{P}_{3} \mathrm{O}_{10} \mathrm{H}_{4} \mathrm{P}_{3} \mathrm{O}_{10} \quad[18], \quad\left[2,6-\left(\mathrm{C}_{2} \mathrm{H}_{5}\right)_{2} \mathrm{C}_{6} \mathrm{H}_{3} \mathrm{NH}_{3}\right]_{2} \mathrm{H}_{3} \mathrm{P}_{3} \mathrm{O}_{10} \quad$ [19], [2,3$\left.\left(\mathrm{CH}_{3}\right)_{2} \mathrm{C}_{6} \mathrm{H}_{3} \mathrm{NH}_{3}\right]_{4} \mathrm{HP}_{3} \mathrm{O}_{10} .2 \mathrm{H}_{2} \mathrm{O}$ [20], $\left[\mathrm{C}_{12} \mathrm{H}_{19} \mathrm{~N}_{2}\right]_{3}\left[\mathrm{H}_{2} \mathrm{P}_{3} \mathrm{O}_{10}\right] .3 \mathrm{H}_{2} \mathrm{O}$ [21] and $\left(\mathrm{C}_{12} \mathrm{H}_{14} \mathrm{~N}_{2} \mathrm{O}\right)_{2} \mathrm{HP}_{3} \mathrm{O}_{10} .2 \mathrm{H}_{2} \mathrm{O}$ [22].

As for the organic materials, the aromatic amines have been widely acted as templates, termed structure directing agents, because of their important characteristics thanks to the presence of delocalized $\pi$-electrons. Piperazine derivatives present an important group of aromatic amines, which are composed of a six-member ring containing the two opposing nitrogen. These latter have been used as organic part in various compounds and are able to form a dication in the boat and chair forms. Owing to their excellent biological, pharmacology and cardiovascular properties, piperazine derivatives are of great significance to the rational design of well-known drugs with various therapeutic uses, such as antimalarial agents [23,24], anti-bacterial agents [25], anti-psychotic agents [26-28], anti-hypertension, antifungal [29], anti-inflammation [30] and cytotoxic. Due the extensive use of these amines in wide variety of medical formulations researcher efforts have focused in the synthesis of new materials consist of piperazine derivates to expand their scope of application.

Within this context, we report in this work the synthesis of a novel triphosphate compound, named (1phenylpiperazinium) trihydrogen triphosphate $\left(\mathrm{C}_{10} \mathrm{H}_{15} \mathrm{~N}_{2}\right)_{2} \mathrm{H}_{3} \mathrm{P}_{3} \mathrm{O}_{10}$, through the method of crystallization. In order to reach a fine description of the architecture of the title compound and provide detailed information about the internal lattice of the crystal, a single crystal X-ray diffraction was used. The optimized geometry was calculated using method based on the density functional theory (DFT) employing B3LYP/6-311+G(d,p) basis sets. Experimental data and theoretical calculations are compared. Furthermore, Hirshfeld surface analysis is required to elucidate the role of intermolecular contacts. A vibrational study was investigated and discussed. Frontier orbitals, Mulliken charges and molecular electrostatic potential of the title compound have been calculated. The optical properties have been also well discussed in detail. Additionally, cell viability studies in the presence of the compound were also conducted in order to assess its biocompatibility and lack of cytotoxicity.

\section{Materials and methods}

\section{Synthesis}

Single crystals of $\left(\mathrm{C}_{10} \mathrm{H}_{15} \mathrm{~N}_{2}\right)_{2} \mathrm{H}_{3} \mathrm{P}_{3} \mathrm{O}_{10}$ were obtained via an acid-base reaction under normal conditions of temperature and pressure. The chemical synthesis of the title compound was carried out in two steps: The triphosphoric acid was first prepared by passing a sodium salt solution of $\mathrm{Na}_{5} \mathrm{P}_{3} \mathrm{O}_{10}$ (a starting material to prepare the organic triphosphates) through an ion exchange resin (Amberlite IR 120), and then an alcoholic solution of 1phenylpiperazine was added drop by drop to this aqueous solution until a $\mathrm{pH}=2$.

Schematically the synthesis reaction is:

$$
2\left(\mathrm{C}_{10} \mathrm{H}_{14} \mathrm{~N}_{2}\right)+\mathrm{H}_{5} \mathrm{P}_{3} \mathrm{O}_{10} \longrightarrow\left(\mathrm{C}_{10} \mathrm{H}_{15} \mathrm{~N}_{2}\right)_{2} \mathrm{H}_{3} \mathrm{P}_{3} \mathrm{O}_{10}
$$

After a few days of slow evaporation at $298 \mathrm{~K}$, colorless transparent crystals appeared in the solution.

\section{X-ray crystallography}

The powder X-ray diffraction (PXRD) was performed using $\mathrm{Cu}-\mathrm{K} \alpha(\lambda=1.5406 \AA)$ radiation on a Bruker D8advance diffractometer, for typical powder patterns, data is collected at $2 \theta$ over the range of $0-40$ degrees. A tiny single crystal of approximate dimension $0.21 \times 0.16 \times 0.14 \mathrm{~mm}^{3}$ was chosen for the diffraction measurement. The data were collected at 293(2) K with an Enraf-Nonius MACH3 four-circle diffractometer, using graphite 
monochromated Mo- $\mathrm{K}_{\alpha}$ radiation $(\lambda=0.71073 \AA)$. The structure was solved and refined with SHELXT [31] and refined using SHELXL [32]. The drawing of the molecular structure was made with DIAMOND [33]. Further details of the structure analysis are reported in Table S1. The hydrogen bonds are given in Table S2. Hirshfeld surface and their associated two-dimensional fingerprint were plotted with Crystal Explorer (version 3.1) software [34] which use the CIF files of the desired compound in order to analyse the intermolecular interactions in the crystal.

\section{Computational methodology}

Gaussian03 program [35] was used for the quantum chemical calculations and the optimized molecular geometries. All the calculation results were visualized with the Gauss-View 4.1 [36]. The structure based on the crystallographic data in the supplementary table was used as starting points at the density functional theory (DFT) with the Becke-three-parameter hybrid exchange functional combined with the Lee-Yang-Parr correlation functional (B3LYP) levels. It is to be noted that the LANL2DZ was used as the basis set. The molecular electrostatic potential (MEP) map, Mulliken population charge and FT-IR spectrum of optimized structure were calculated at the same basis set. The calculated vibration frequencies were scaled using the scaling factor 0.9614 [37]. The absence of imaginary frequencies in the calculated vibrational spectrum confirms that the structure corresponds to minimum energy.

\section{Spectroscopic measurements}

A Nicolet IR200 FTIR equipped with a diamond micro-ATR was used to characterize the infrared stretching and bending bands of the (1-phenylpiperazinium) trihydrogen triphosphate in the $4000-400 \mathrm{~cm}^{-1}$ range.

Solid state UV-Vis absorption spectra were performed on a Perkin Elmer Lambda 35 spectrophotometer in the range of $200-800 \mathrm{~nm}$.

Emission spectrum was performed using the PerkinElmer LS55 fluorescence spectrometer equipped with a 450 W xenon lamp as the excitation source using solid sample at room temperature.

All NMR experiments were carried out using $\mathrm{D}_{2} \mathrm{O}$ as solvent on a Bruker Avance III spectrometer operating at $400 \mathrm{MHz}$.

\section{Biological assays}

After in vitro characterization, the new organic triphosphate synthesized was evaluated in experiments with cells. These additional studies were undertaken to assess and to exclude any toxic effect of the compound. For these experiments, RAW 264.7 murine macrophages cell lines were used as model system. The cells were routinely grown in a DMEM (Dubecco's Modified Eagle's Medium /Nutrient Mixture F-12 Ham containing 10 \% fetal calf serum (FCS) and 1\% penicillin/streptomycin purchased from Sigma-Aldrich. The maintenance of the cell culture was carried out according to standard protocols provided by the European Collection of Authenticated Cell Cultures (ECACC). To study the effect of the synthesized compound, cells were seeded in 24-well culture plates at a density of $1.510^{6}$ cells per well and treated with the corresponding concentration of compound (ranging from $100 \mu \mathrm{M}$ to $10 \mathrm{nM}$ ) for $24 \mathrm{~h}$. Then, the medium was gently aspirated and cells were washed with PBS. Then, $200 \mu \mathrm{L}$ of a solution of a MTT $\left(0.1 \mathrm{mg} \cdot \mathrm{ml}^{-1}\right)$ in fresh medium were added and the cells were incubated for $45 \mathrm{~min}$ at $37^{\circ} \mathrm{C}$. Finally, the medium was aspirated and $200 \mu \mathrm{L}$ of DMSO were added to measure absorbance of each well at $492 \mathrm{~nm}$ using a 96-well multiwell plate reader (Wallac 1420 VICTOR2TM, Perkin Elmer). Three independent experiments were carried out.

\section{Results and discussion}




\section{Description of the crystal structure}

X-ray diffraction patterns of the experimental and the simulated studied sample are shown in Fig. 1. Both the peak positions displayed in the measured patterns and the simulated patterns are in good line. This result reveals clearly that the synthesis product is in pure phase. A slight difference in the positions, widths, and intensities of some peaks can be observed, which are ascribed to the different temperatures used for the single crystal (293 K) and powder diffraction measurements (room temperature). It is noted that there is some of the extra unexpected lines with weak intensities are observed which is certainly due to the presence of some impurities in the powder sample, that are absent in the single crystals state.

An ORTEP plot of $\left(\mathrm{C}_{10} \mathrm{H}_{15} \mathrm{~N}_{2}\right)_{2} \mathrm{H}_{3} \mathrm{P}_{3} \mathrm{O}_{10}$ is shown in Fig. S1. This structural model in which the asymmetric unit contains one inorganic anion $\left[\mathrm{H}_{3} \mathrm{P}_{3} \mathrm{O}_{10}\right]^{2-}$ and two organic cations, denoted $\left[\mathrm{C}_{10} \mathrm{H}_{15} \mathrm{~N}_{2}\right]^{+}$crystallographically independent.

Fig. 2 displays the projection of the structure of (1-phenylpiperazinium) trihydrogen triphosphate in the (ac) plane. Indeed the examination of the latter manifests the existence of infinite layers of anions $\left[\mathrm{H}_{3} \mathrm{P}_{3} \mathrm{O}_{10}\right]^{2-}$ located at $\mathrm{z}=0$ between them, the organic cations are inserted giving rise to a three-dimensional network through $\mathrm{N}$ $\mathrm{H} \cdots \mathrm{O}$ and $\mathrm{C}-\mathrm{H} \cdots \mathrm{O}$ hydrogen bonds. Inside such a layer, two $\mathrm{H}_{3} \mathrm{P}_{3} \mathrm{O}_{10}{ }^{2-}$ anions are linked together via strong $\mathrm{O}(1)-\mathrm{H}(8) \cdots \mathrm{O}(10)$ hydrogen bond to form $\mathrm{H}_{6} \mathrm{P}_{6} \mathrm{O}_{20}{ }^{4-}$ cyclic units (Fig. S2(a)) which are interconnected by strong hydrogen bond interactions $[\mathrm{O}(9) \cdots \mathrm{O}(8): 2.624(4) \AA, \mathrm{O}(1) \cdots \mathrm{O}(10): 2.557(4) \AA]$ to develop a layer parallel to (a,b) plane. These associations created a $R_{2}^{2}(16)$ ring graph set as shown in Fig. S2(b).

The $\mathrm{P}_{3} \mathrm{O}_{10}{ }^{5-}$ is formed by three independent tetrahedra $\mathrm{PO}_{4}$ groups which are bonded via two bridge oxygen $\mathrm{O} 4$ and $\mathrm{O} 5 .\left[\mathrm{H}_{2} \mathrm{PO}_{3}-\mathrm{O}-\mathrm{PO}-\mathrm{O}-\mathrm{HPO}_{3}\right]$ is the detailed geometry of the triphosphate group. Table 1 depicts the $\mathrm{PO}_{4}$ distances inside the $\mathrm{H}_{3} \mathrm{P}_{3} \mathrm{O}_{10}{ }^{2-}$ anion, as usually observed for all condensed phosphates, there are different types of $\mathrm{PO}$ distances inside the $\mathrm{PO}_{4}$ tetrahedron.

Table 1. Main interatomic distances $(\AA)$ and bond angles $\left({ }^{\circ}\right)$ of $\mathrm{H}_{3} \mathrm{P}_{3} \mathrm{O}_{10}{ }^{2-}$.

\begin{tabular}{|c|c|c|c|c|}
\hline $\mathbf{P}(\mathbf{1})$ & $\mathbf{O}(7)$ & $\mathbf{O}(5)$ & $\mathbf{O}(6)$ & $\mathbf{O}(4)$ \\
\hline $\mathrm{O}(7)$ & $1.3190(15)$ & $101.30(10)$ & $112.17(12)$ & 113.91(11) \\
\hline $\mathrm{O}(5)$ & $2.1886(21)$ & $\underline{1.5070(16)}$ & $117.54(10)$ & $98.52(10)$ \\
\hline $\mathrm{O}(6)$ & $2.4264(28)$ & $2.6564(24)$ & $\underline{1.5991(19)}$ & $112.39(9)$ \\
\hline $\mathrm{O}(4)$ & $2.6146(25)$ & $2.5011(25)$ & $2.814(3)$ & $\underline{1.7852(5)}$ \\
\hline $\mathbf{P}(2)$ & $\mathbf{O}(3)$ & $\mathbf{O}(\mathbf{1})$ & $\mathbf{O}(2)$ & $\mathbf{O}(4)$ \\
\hline $\mathrm{O}(3)$ & $\underline{1.4258(18)}$ & 110.01(12) & $121.26(12)$ & $109.60(11)$ \\
\hline $\mathrm{O}(1)$ & $2.3561(27)$ & $1.450(2)$ & $95.94(13)$ & $115.88(13)$ \\
\hline $\mathrm{O}(2)$ & $2.5519(26)$ & $2.1854(24)$ & $1.5019(19)$ & $104.35(11)$ \\
\hline $\mathrm{O}(4)$ & $2.6618(29)$ & $2.7781(28)$ & $2.6308(32)$ & $1.820(2)$ \\
\hline $\mathbf{P}(3)$ & $\mathbf{O}(5)$ & $\mathbf{O}(\mathbf{8})$ & $\mathbf{O}(\mathbf{1 0})$ & $\mathbf{O}(9)$ \\
\hline $\mathrm{O}(5)$ & $\underline{1.3786(15)}$ & $105.77(10)$ & 101.72(12) & $100.91(12)$ \\
\hline $\mathrm{O}(8)$ & $2.2818(24)$ & $\underline{1.4822(18)}$ & $113.89(14)$ & $113.82(11)$ \\
\hline $\mathrm{O}(10)$ & $2.2831(22)$ & $2.5508(28)$ & $1.561(2)$ & $118.06(16)$ \\
\hline $\mathrm{O}(9)$ & $2.4308(40)$ & 2.7191(33) & $2.8476(39)$ & $\underline{1.758(3)}$ \\
\hline \multicolumn{2}{|c|}{$\mathrm{P}(2)-\mathrm{P}(1)=3.357(10)$} & \multicolumn{2}{|c|}{$\mathrm{P}(1)-\mathrm{O}(4)-\mathrm{P}(2)=137.31(10)$} & \\
\hline \multicolumn{2}{|c|}{$\mathrm{P}(1)-\mathrm{P}(3)=2.604(10)$} & \multicolumn{2}{|c|}{$\mathrm{P}(1)-\mathrm{O}(5)-\mathrm{P}(3)=128.87(12)$} & \\
\hline \multicolumn{2}{|c|}{$\mathrm{P}(2)-\mathrm{O}(1)-\mathrm{H}(8)=110.06(3)$} & \multicolumn{2}{|c|}{$\mathrm{O}(1)-\mathrm{H}(8)=0.99(6)$} & \\
\hline \multicolumn{2}{|c|}{$\mathrm{P}(2)-\mathrm{O}(2)-\mathrm{H}(9)=102.60(3)$} & \multicolumn{2}{|c|}{$\mathrm{O}(2)-\mathrm{H}(9)=0.89(4)$} & \\
\hline \multicolumn{2}{|c|}{$\mathrm{P}(3)-\mathrm{O}(9)-\mathrm{H}(7)=118.33(4)$} & \multicolumn{2}{|c|}{$\mathrm{O}(9)-\mathrm{H}(7)=0.75(5)$} & \\
\hline
\end{tabular}


The average values of the distorsion indices were calculated using the Baur method [38] which is based on the following formula:

$$
\mathrm{ID}(\mathrm{PO})=\frac{\sum_{i}\left|P O_{i}-P O_{m}\right|}{\sum_{i} P O_{i}}, \mathrm{ID}(\mathrm{OO})=\frac{\sum_{i}\left|O O_{i}-O O_{m}\right|}{\sum_{i} O O_{i}} \text { and ID }(\mathrm{OPO})=\frac{\sum_{i}\left|O P O_{i}-O P O_{m}\right|}{\sum_{i} O P O_{i}}
$$

The results of the calculation are [DI $(\mathrm{OPO})=0.034$; DI $(\mathrm{PO})=0.020$; and DI $(\mathrm{OO})=0.017]$. Reviewing these values we can conclude that the distortion in the P-O distances is slightly higher than O-O distances. In this structure, the $\mathrm{PO}_{4}$ group can be regarded as a regular arrangement of oxygen atoms with the phosphorus atom softly displaced from the gravity center. The two crystallographically independent organic cations adopt a chair conformation, which is the most stable conformation. The conformation of the piperazine six-membered ring can be described in terms of Cremer \& Pople puckering coordinates [39]. In this crystal structure, the puckering parameters are as follows: $\mathrm{QT}=0.5174 \AA, \mathrm{q} 2=0.0123 \AA, \mathrm{q} 3=0.5172 \AA, \theta=1.36^{\circ}, \phi=-61.79^{\circ}$ for the (N2$\mathrm{C} 10-\mathrm{C} 9-\mathrm{N} 1-\mathrm{C} 7-\mathrm{C} 8)$ ring and $\mathrm{QT}=0.5432 \AA, \mathrm{q} 2=0.0432 \AA, \mathrm{q} 3=0.5415 \AA, \theta=4.56^{\circ}, \phi=176.67^{\circ}$ for the $(\mathrm{N} 4-$ C19-C18-N3-C17-C20) ring. DFT calculations were applied on $\left(\mathrm{C}_{10} \mathrm{H}_{15} \mathrm{~N}_{2}\right)_{2} \mathrm{H}_{3} \mathrm{P}_{3} \mathrm{O}_{10}$ at B3LYP/LANL2DZ level. The optimized structure of the title compound is illustrated in Fig. 3.

The experimental and theoretical structural parameters of the studied compound are given in Table 2. After a careful comparison, we find that the optimized parameters such as bond lengths, bond angles and torsion angles are compatible with those determined using single crystal X-ray diffraction method. The slight minor deviations observed can be explained by the fact that the experimental data is obtained in the solid state in the gaseous phase whereas in the theoretical methods the molecular interactions are not taken into account. As shown the optimized parameters (bond lengths, bond angles) are very close with the experimental data (Fig. S3).

Table 2. Some selected geometric parameters for $\left(\mathrm{C}_{10} \mathrm{H}_{15} \mathrm{~N}_{2}\right)_{2} \mathrm{H}_{3} \mathrm{P}_{3} \mathrm{O}_{10}\left(\AA,{ }^{\circ}\right)$.

\begin{tabular}{|c|c|c|}
\hline $\begin{array}{l}\text { Geometric } \\
\text { Parameters }\end{array}$ & $\begin{array}{c}\text { Experimental } \\
{[X-\text { ray diffraction] }}\end{array}$ & $\begin{array}{c}\text { Calculated } \\
\text { DFT }\end{array}$ \\
\hline \multicolumn{3}{|l|}{ Bond lengths $(\AA)$} \\
\hline $\mathrm{P} 1-\mathrm{O} 4$ & $1.785(2)$ & 1.706 \\
\hline $\mathrm{P} 1-\mathrm{O} 5$ & $1.506(2)$ & 1.579 \\
\hline $\mathrm{P} 1-\mathrm{O} 6$ & $1.598(2)$ & 1.658 \\
\hline $\mathrm{P} 2-\mathrm{O} 1$ & $1.450(2)$ & 1.556 \\
\hline $\mathrm{P} 2-\mathrm{O} 2$ & $1.500(2)$ & 1.646 \\
\hline $\mathrm{P} 2-\mathrm{O} 3$ & $1.425(2)$ & 1.568 \\
\hline $\mathrm{P} 3-\mathrm{O} 8$ & $1.481(2)$ & 1.627 \\
\hline $\mathrm{N} 1-\mathrm{C} 1$ & $1.435(3)$ & 1.443 \\
\hline $\mathrm{N} 1-\mathrm{C} 7$ & $1.550(4)$ & 1.474 \\
\hline $\mathrm{N} 2-\mathrm{C} 8$ & $1.610(4)$ & 1.518 \\
\hline $\mathrm{N} 2-\mathrm{C} 10$ & $1.576(4)$ & 1.508 \\
\hline N3-C11 & $1.416(3)$ & 1.428 \\
\hline N3-C18 & $1.336(3)$ & 1.456 \\
\hline $\mathrm{N} 4-\mathrm{C} 19$ & $1.671(4)$ & 1.513 \\
\hline \multicolumn{3}{|l|}{ Bond angles ( $\left.{ }^{\circ}\right)$} \\
\hline $\mathrm{O} 1-\mathrm{P} 2-\mathrm{O} 2$ & $95.55(15)$ & 100.8 \\
\hline $\mathrm{O} 4-\mathrm{P} 2-\mathrm{O} 1$ & $115.89(14)$ & 112.68 \\
\hline O8-P3-O9 & $113.79(11)$ & 113.16 \\
\hline $\mathrm{P} 1-\mathrm{O} 5-\mathrm{P} 3$ & $128.85(13)$ & 134.98 \\
\hline $\mathrm{C} 1-\mathrm{N} 1-\mathrm{C} 7$ & $116.6(2)$ & 115.84 \\
\hline $\mathrm{C} 11-\mathrm{N} 3-\mathrm{C} 18$ & $115.7(2)$ & 110.50 \\
\hline $\mathrm{C} 8-\mathrm{N} 2-\mathrm{C} 10$ & $121.8(2)$ & 122.07 \\
\hline $\mathrm{C} 19-\mathrm{N} 4-\mathrm{C} 20$ & $115.0(2)$ & 112.19 \\
\hline
\end{tabular}




\section{Hirshfeld surface studies}

Surface analysis is a powerful tool in the visualization and exploration of the intermolecular interactions in the crystal structure of compound. Crystal Explorer 3.1 program which processes structure input files in the CIF format was used to calculate Hirshfeld surfaces [40] and their associated two-dimensional fingerprint plots [41] which summarize all the intermolecular interactions. The normalized contact distance $\left(d_{\text {norm }}\right)$ based on $d_{e}$ and $d_{i}$ are defined as the distance from the surface to the nearest atom external and internal to the surface, respectively is calculated via the following expression:

$$
d_{n o r m}=\frac{d_{i}-r_{i}^{v d w}}{r_{i}^{v d w}}+\frac{d_{e}-r_{e}^{v d w}}{r_{e}^{v d w}}
$$

With $r_{i}^{v d w}$ is the van der Walls radius of the atom that lies inside the surface of Hirshfeld, while $r_{e}^{v d w}$ is the van der Walls radius of the atom that lies outside of the surface of Hirshfeld.

For describing the surface characteristics of the crystal structure, Hirshfeld surface and two-dimensional fingerprint plots are useful tools using Crystal Explorer package. Hirshfeld surface of $\left(\mathrm{C}_{10} \mathrm{H}_{15} \mathrm{~N}_{2}\right)_{2} \mathrm{H}_{3} \mathrm{P}_{3} \mathrm{O}_{10}$ with mapped $d_{\text {norm }}$ is portrayed in Fig. 4.

The surface of the three-dimensional $d_{n o r m}$ was obtained in the range -0.830 (red) to 1.414 (blue) using a standard (high) surface resolution for the title compound. A red-white-blue color scheme is used for the analysis of the molecular. The inter-contacts included in hydrogen bonds are represented with the red spots over Hirshfeld surface. The blue fields indicate areas where neighboring atoms are too far away to interact with each other [4246] and the white color is used for the contacts around the sum of van der Waals radii (vdW). The red regions are apparent above the oxygen atoms participating in the $\mathrm{C}-\mathrm{H} \cdots \mathrm{O}, \mathrm{N}-\mathrm{H} \cdots \mathrm{O}$ and $\mathrm{O}-\mathrm{H} \cdots \mathrm{O}$ contacts.

Examination of decomposed 2D fingerprint plots (Fig. 5) shows that the $\mathrm{O} \cdots \mathrm{H} / \mathrm{H} \cdots \mathrm{O}$ contacts appearing as two narrow long spikes represent the largest relative contribution, amounting to $43.7 \%$ in the compound. Furthermore, the $\mathrm{O} \cdots \mathrm{H} / \mathrm{H} \cdots \mathrm{O}$ contacts indicate the presence of intermolecular $\mathrm{C}-\mathrm{H} \cdots \mathrm{O}, \mathrm{N}-\mathrm{H} \cdots \mathrm{O}$ and $\mathrm{O}-\mathrm{H} \cdots \mathrm{O}$ interactions, respectively. The $\mathrm{H} \cdots \mathrm{H}$ contact constitute the second major frequent interactions in view of the abundance of hydrogen on the molecular surface. The decomposition of the fingerprint plots shows that $\mathrm{H} \cdots \mathrm{H}$ covers $39.7 \%$ of the total surface. The $\mathrm{C} \cdots \mathrm{H} / \mathrm{H} \cdots \mathrm{C}$ contacts with percentage contributions of $12.9 \%$ appear as two broad short spikes. The $\mathrm{H} \cdots \mathrm{N} / \mathrm{N} \cdots \mathrm{H}$ and $\mathrm{O} \cdots \mathrm{O}$ contacts comprise $2.1 \%$ and $1 \%$ respectively. C $\cdots \mathrm{C}$ and $\mathrm{P} \ldots \mathrm{O} / \mathrm{O} \cdots \mathrm{P}$ contacts have a small percentage $(0.3 \%$ and $0.2 \%)$ on the Hirshfeld surface.

Thus, fingerprint graphics and the molecular Hirshfeld surface are a good way to understand the contributions of diverse contacts that assist stabilize molecular structures.

\section{IR Spectroscopy}

The IR spectroscopy has been used due to its usefulness in the determination and the identification of the frequencies of the vibrations on the crystal structure. The theoretical IR spectrum, calculated by using DFT/ B3LYP method with LANL2DZ basis set, was made on the optimized geometries of the compound. The scaling factor is taken as 0.9614 to reduce the discrepancy between the experimental frequencies and the computational methods. For visual comparison, the theoretical IR spectrum and the experimental one are schematically illustrated in Fig. 6. The detailed assignments of the scaled calculated and vibrational experimental modes are quoted in Table 3.

The bands appeared in the region of $1300-1100 \mathrm{~cm}^{-1}$, which is an important region for the identification of the stretching vibrations, asymmetric symmetric, of $\mathrm{PO}_{2}$ central atomic group. The peaks detected between 1259 and 
$966 \mathrm{~cm}^{-1}$ are attributed to the stretching vibrations of $\mathrm{PO}_{3}$ terminal atomic groups [47]. These vibrations are well observed by DFT calculation in the range 1086- $959 \mathrm{~cm}^{-1}$. The stretching P-O-P modes are located in the 896$687 \mathrm{~cm}^{-1}$ region [48]. This mode predicted by DFT calculation at $840 \mathrm{~cm}^{-1}$. The bands which appear between 600-400 correspond to the bending vibrations of $\mathrm{PO}_{3}$ terminal groups while the DFT calculation gives these modes between $673-577 \mathrm{~cm}^{-1}$.

The bands which located in the high frequency region, those between $3100-3000 \mathrm{~cm}^{-1}$ are generally due to the asymmetric stretching vibration $v_{\mathrm{as}}(\mathrm{C}-\mathrm{H})$ of aromatic ring, while the symmetric stretching vibration $v_{\mathrm{s}}(\mathrm{C}-\mathrm{H})$ of the cyclic ring are displayed in the range of 2990-2900 $\mathrm{cm}^{-1}$. It is clearly observed that the band in $2836-2250$ $\mathrm{cm}^{-1}$ correspond to the stretching vibrations of $-\mathrm{NH}_{2}{ }^{+},-\mathrm{CH}_{2}$ and $\mathrm{N}-\mathrm{H}$ group. The theoretical calculations have predicted the stretching $-\mathrm{NH}_{2}$ and $\mathrm{C}-\mathrm{H}$ mode at $3070 \mathrm{~cm}^{-1}$. It is well known that the wavenumber of the $\mathrm{C}=\mathrm{C}$ stretching vibration, known as semicircle stretching is observed normally between $1600-1400 \mathrm{~cm}^{-1}$ [49]. In this study, the peaks from 1644 to $1325 \mathrm{~cm}^{-1}$ are attributed to the symmetric and asymmetric stretching vibrations $v(\mathrm{C}=\mathrm{C})$, the deformation modes $\delta(\mathrm{N}-\mathrm{H})$ and $v(\mathrm{O}-\mathrm{H})$ of $\mathrm{P}-\mathrm{OH}$ groups. The theoretical calculations show that the band corresponding to the $v(C=C)$ are detected at $1590 \mathrm{~cm}^{-1}$. The bands between $1455-1333 \mathrm{~cm}^{-1}$ are assigned to $-\mathrm{CH}_{2}$ deformation modes. The bands situated at 1260 and $1168 \mathrm{~cm}^{-1}$ are due to $(\mathrm{C}-\mathrm{N})$ stretching. The peak at $1089 \mathrm{~cm}^{-1}$ is assigned to asymmetric and symmetric C-C stretching modes. Bands detected between $965-902 \mathrm{~cm}^{-}$ ${ }^{1}$ are attributed to (C-H) out-of-plane deformation. Bands which appear between 764 and $691 \mathrm{~cm}^{-1}$ are assigned to $(\mathrm{C}-\mathrm{N})$ and $(\mathrm{C}-\mathrm{C})$ out-of-plane deformation. Finally, those observed at $569-496 \mathrm{~cm}^{-1}$ are attributed to the mode of deformation of the group $\delta(\mathrm{C}=\mathrm{C})$ out of the plane. It is obvious that the theoretical IR spectrum shows a good conformity with the experimental one (Fig. S4).

Table 3. Comparaison of the observed and calculated vibrational mode frequencies.

\begin{tabular}{|l|l|l|}
\hline \multicolumn{1}{|c|}{ Assignments } & \multicolumn{1}{|c|}{$\begin{array}{c}\text { Experimental IR } \\
\left(\mathrm{cm}^{-1}\right)\end{array}$} & \multicolumn{1}{c|}{$\begin{array}{c}\text { Calculated } \\
\text { B3LYP/LANL2DZ }\end{array}$} \\
\hline$v_{\text {asym }}\left(\mathrm{NH}_{2}\right)$ & - & 3326 \\
\hline$v_{\text {sym }}\left(\mathrm{NH}_{2}\right)+v_{\text {ar }}(\mathrm{CH})$ & $3100-3000$ & 3070 \\
\hline$v_{\text {sym }}\left(\mathrm{CH}_{2}\right)$ & $3000-2800$ & 2894 \\
\hline$\beta_{\text {in plane }}\left(\mathrm{NH}_{2}\right)$ & - & 1738 \\
\hline$v(\mathrm{C}=\mathrm{C})$ & $1644-1325$ & 1590 \\
\hline$\beta_{\text {in plane, ar }}(\mathrm{CH})$ & - & 1475 \\
\hline$\beta(\mathrm{OH})$ & - & $1418,1273,1201$ \\
\hline$\left.v(\mathrm{PO})_{3}\right)$ & $1259-966$ & $1086,1034,959$ \\
\hline$v(\mathrm{POP})$ & $896-687$ & 840 \\
\hline$\beta\left(\mathrm{PO}_{3}\right)$ & $600-400$ & 673,577 \\
\hline
\end{tabular}

\section{Frontier molecular orbitals (FMOs) analysis}

The highest occupied molecular orbital (HOMO), which is the orbital that acts as an electron donor whereas the lowest unoccupied molecular orbital (LUMO), which is the orbital that acts as electron acceptor, and their electronic band gap, are the most important parameters in the field of theoretical quantum chemistry for understanding the chemical reactivity of the molecules and their stability [51-53]. The electron distributions of the HOMO-LUMO energy for the synthesized compound computed at the Becke's three parameter functional and the Lee-Yang-Parr functional (B3LYP) with the basis set LANL2DZ are depicted in Fig. 7.

The HOMO and LUMO energies, the energy gap and other chemical reactivity descriptors that could be used to predict the chemical stability and reactivity, such as the ionization potential (I), the electron affinity (A), the 
electronegativity $(\chi)$ the softness $(\sigma)$ and the hardness $(\eta)$ for the $\left(\mathrm{C}_{10} \mathrm{H}_{15} \mathrm{~N}_{2}\right)_{2} \mathrm{H}_{3} \mathrm{P}_{3} \mathrm{O}_{10}$ molecule were also calculated at the same basis set and the results are reported in the Table 4. For the title compound, the computed gas phase HOMO and LUMO energies are $-8.21 \mathrm{eV}$ and $-4.94 \mathrm{eV}$ respectively, whereas the energy gap is found $3.27 \mathrm{eV}$. This value obtained by DFT calculations is in good agreement with the optical band gaps calculated from the UV-Vis absorption $(2.82 \mathrm{eV})$. The slight difference is probably due to the adopted approximations in the computation.

Table 4. The calculated parameters of $\left(\mathrm{C}_{10} \mathrm{H}_{15} \mathrm{~N}_{2}\right)_{2} \mathrm{H}_{3} \mathrm{P}_{3} \mathrm{O}_{10}$ using B3LYP/LANL2DZ level.

\begin{tabular}{|l|l|l|}
\hline \multicolumn{2}{|c|}{ Parameters } & \multicolumn{1}{c|}{ B3LYP/LANL2DZ } \\
\hline HOMO energy & $\mathrm{E}_{\mathrm{HOMO}}(\mathrm{eV})$ & -8.21 \\
\hline LUMO energy & $\mathrm{E}_{\mathrm{LUMO}}(\mathrm{eV})$ & -4.94 \\
\hline Energy gap & $\Delta \mathrm{E}=\mathrm{E}_{\mathrm{HOMO}}-\mathrm{E}_{\mathrm{LUMO}}(\mathrm{eV})$ & -3.27 \\
\hline Iionization potential & $\mathrm{IP}=-\mathrm{E}_{\mathrm{HOMO}}(\mathrm{eV})$ & 8.21 \\
\hline Electron affinity & $\mathrm{EA}=-\mathrm{E}_{\mathrm{LUMO}}(\mathrm{eV})$ & 4.94 \\
\hline Electronegativity & $\chi=(\mathrm{IP}+\mathrm{EA}) / 2(\mathrm{eV})$ & 6.58 \\
\hline Hardness & $\eta=(\mathrm{IP}-\mathrm{EA}) / 2(\mathrm{eV})$ & 1.64 \\
\hline Softness & $\sigma=1 / \eta(\mathrm{eV})$ & 0.30 \\
\hline
\end{tabular}

The large values of the electronic band gaps for $\left(\mathrm{C}_{10} \mathrm{H}_{15} \mathrm{~N}_{2}\right)_{2} \mathrm{H}_{3} \mathrm{P}_{3} \mathrm{O}_{10}$, favor their hard nature with low chemical reactivity and high stability. The chemical hardness $(\eta)$ can calculated as $\left[-\left(\mathrm{E}_{\mathrm{HOMO}}-\mathrm{E}_{\mathrm{LUMO}}\right) / 2\right]$ is found $1.64 \mathrm{eV}$, this value reflects that the compound is chemically stable. The softness $(\sigma)$, which is the reciprocal of the hardness can calculated as $\left[-2\left(\mathrm{E}_{\mathrm{HOMO}}-\mathrm{E}_{\mathrm{LUMO}}\right)\right]$, is found $0.30 \mathrm{eV}$. The obtained small hardness parameters indicate that the title compound is a hard system which is not prone to chemical reaction and prove also that this compound presents high kinetic stability. The chemical reactivity descriptors are used the following equations $[54,55]:$

The electron affinity (EA)

The ionization potential (IP)

$$
\begin{aligned}
& \mathrm{EA}=-\mathrm{E}_{\text {LUMO }} \\
& \mathrm{IP}=-\mathrm{E}_{\text {HOMO }}
\end{aligned}
$$

Absolute electronegativity ( $\chi$ ) and chemical potential $(\mu)$

Absolute hardness $(\eta) \quad \eta=\frac{\text { IP-EA }}{2}$

Softness $(\sigma)$

$$
\sigma=\frac{1}{\eta}
$$

\section{Molecular electrostatic potential (MEP)}

The molecular electrostatic potential (MEP) is a powerful descriptor and an effective approach in understanding the intermolecular and intramolecular interactions in the solid states and offer quite accurate information about sites for electrophilic and nucleophilic. In other word, it's able to convey information about the interaction, active sites and the charge distribution of a molecule. Calculation of MEP was conducted at a high theoretical DFT level using B3LYP/LANL2DZ level of theory and is given in Fig. 8. As you can see in the three dimensional model of the electrostatic potential map a color spectrum ranging from red to dark blue, with red as the lowest electrostatic potential energy value indicates the nucleophilic region with rich electrons in the environment, blue-colored region as the highest, is employed to convey the varying intensities of the electrostatic potential energy values and the green color stands for the parts of the molecule where the electrostatic potentials are close to zero (neutral areas). The electrostatic potential increases in the order red $<$ orange $<$ yellow $<$ green 
$<$ blue. These sites provide information about the region in which the molecules can interact with each other and the hydrogen bonding contacts [56-58]. Fig. 8 demonstrates that the reactive sites are localized around the P-O group, this region (deepest red) have the most negative potential spots over the oxygen atoms due to the C$\mathrm{H} \cdots \mathrm{O}, \mathrm{N}-\mathrm{H} \cdots \mathrm{O}$ and $\mathrm{O}-\mathrm{H} \cdots \mathrm{O}$ interactions in the crystal structure. The negative potential value $(-0.123$ a.u.) displays the strongest repulsion. The most positive region for $\left(\mathrm{C}_{10} \mathrm{H}_{15} \mathrm{~N}_{2}\right)_{2} \mathrm{H}_{3} \mathrm{P}_{3} \mathrm{O}_{10}$ is placed on the hydrogen atoms and shows the strongest attraction sites involving the 1-phenylpiperazinium moieties.

\section{Mulliken population analysis}

Mulliken population method was used to obtain the total atomic charge distributions and to describe the electronic structure, molecular dipole moment, charge transfer mechanism and polarizability. The Mulliken charges for the molecule were performed with B3LYP/LanL2DZ level of theory in the gas phase. The atomic charges play a key role in the application of quantum mechanical simulations [59]. The charge distribution on atoms is important in explaining donor and acceptor pairs and gaining insight into the overall activity of the compound. Mulliken is highly effective in detecting nucleophilic or electrophilic attacks and regions sensitive to other molecular interactions. The corresponding Mulliken charges are tabulated in Table 5.

Table 5. Main interatomic distances $(\AA)$ and bond angles $\left({ }^{\circ}\right)$ of $\mathrm{H}_{3} \mathrm{P}_{3} \mathrm{O}_{10}{ }^{2-}$.

\begin{tabular}{|c|c|c|c|c|c|}
\hline Atom & Mulliken Charges & Atom & Mulliken Charges & Atom & Mulliken Charges \\
\hline P1 & 1.595940 & C8 & 0.125834 & H7B & 0.270348 \\
\hline P2 & 1.643224 & C9 & 0.107889 & H8 & 0.466642 \\
\hline P3 & 1.569168 & C10 & 0.115469 & H8A & 0.229601 \\
\hline N1 & -0.233178 & C11 & 0.450929 & H8B & 0.294974 \\
\hline N2 & 0.377951 & C12 & -0.071320 & H9 & 0.414848 \\
\hline N3 & -0.230890 & C13 & 0.012687 & H9A & 0.235052 \\
\hline N4 & 0.351232 & C14 & -0.023401 & H9B & 0.241049 \\
\hline O1 & -0.893880 & C15 & 0.012330 & H10A & 0.215997 \\
\hline O2 & -0.285345 & C16 & -0.159340 & H10B & 0.253230 \\
\hline O3 & -0.817813 & C17 & 0.059153 & H12 & 0.298006 \\
\hline O4 & -0.836900 & C18 & 0.187230 & H13 & 0.242470 \\
\hline O5 & -0.908279 & C19 & 0.192000 & H14 & 0.228287 \\
\hline O6 & -0.706333 & C20 & 0.057147 & H15 & 0.221934 \\
\hline O7 & -0.798426 & H2 & 0.248241 & H16 & 0.234190 \\
\hline O8 & -0.288944 & H2A & 0.482747 & H17A & 0.241316 \\
\hline O9 & -0.294988 & H2B & 0.363695 & H17B & 0.191109 \\
\hline O10 & -0.655541 & H3 & 0.225198 & H18A & 0.220024 \\
\hline C1 & 0.389041 & H4 & 0.229381 & H18B & 0.339960 \\
\hline C2 & -0.159094 & H4A & 0.496451 & H19A & 0.310768 \\
\hline C3 & 0.015923 & H4B & 0.330616 & H19B & 0.237912 \\
\hline C4 & -0.015785 & H5 & 0.241883 & H20A & 0.204472 \\
\hline C5 & -0.007457 & H6 & 0.343693 & H20B & 0.250085 \\
\hline C6 & -0.036663 & H7 & 0.415521 & & \\
\hline C7 & 0.160428 & H7A & 0.228661 & & \\
\hline
\end{tabular}

From the results it is clear that, all hydrogen atoms in the molecule have a positive charge. Also, all phosphorus atoms $\mathrm{P} 1, \mathrm{P} 2$ and $\mathrm{P} 3$ possess positive. It is worthy to mention that the oxygen atoms (O1, O3, O6, $\mathrm{O} 7$ and $\mathrm{O} 10)$ displayed maximum negative charges. Because of these oxygen atoms' environment, all phosphorus atoms have higher Mulliken atomic charge than other positive atoms. The maximum of positive charges of carbon and nitrogen atoms were bonded to oxygen atoms. The results are supported with electrophilic/nucleophilic nature of MEP surface. 


\section{NMR spectroscopy}

${ }^{13} \mathrm{C}$ NMR spectrum of the title compound is shown on (Fig. S5a). Since the organic motif is symmetric and contains ten carbon atoms, each one has its own electronic environment. But as shown from the spectrum, it exhibits only six resonances. According to previous studies [60,61], the carbons observed between 40-50 ppm are assigned to the nitrogen- bonded $\mathrm{CH}_{2}$ groups while the aromatic carbons are typically occurs between 115 $150 \mathrm{ppm}$. It is obvious that the peak at $149 \mathrm{ppm}$ correspond to the carbon bonded to the strongly attracting nitrogen atom. The ${ }^{1} \mathrm{H}$ NMR spectrum of the title compound is shown in (Fig. S5b), a total often peaks were observed corresponding to fifteen hydrogens. The signals observed at $3.40 \mathrm{ppm}$ and $3.41 \mathrm{ppm}$ are assigned to $\mathrm{C}(8,10) \mathrm{H}_{2}$ and $\mathrm{C}(7,11) \mathrm{H}_{2}$ respectively. At $4.7 \mathrm{ppm}$, there is a simple signal which is normally the chemical shift of the water proton (as solvent). It is important to note that the range [6-7.5ppm] is a common zone for aromatic ring protons. The triplet associated with the signals $7.05 \mathrm{ppm}, 7.07 \mathrm{ppm}$ and $7.08 \mathrm{ppm}$ is attributed to $\mathrm{C}(5) \mathrm{H}$. However, the ${ }^{1} \mathrm{H}$ signals of $\mathrm{C}(1) \mathrm{H}$ and $\mathrm{C}(3) \mathrm{H}$ appear at $7.11 \mathrm{ppm}$ and $7.13 \mathrm{ppm}$. Finally, the $\mathrm{C}(6) \mathrm{H}$ and $\mathrm{C}(4) \mathrm{H}$ is indeed observed at $7.35 \mathrm{ppm}, 7.37 \mathrm{ppm}$ and $7.39 \mathrm{ppm}$.

\section{UV-Vis Absorption}

The solid state UV-Vis absorption spectrum of the entitled compound, measured at room temperature in the range 200-800 nm, is presented in Fig. S6. As can be seen, there are two distinct peaks with different intensities and wavelength are observed in the absorption spectrum. The intense peak around $294 \mathrm{~nm}$ can be ascribed to the $\pi-\pi^{*}$ transition of the aromatic ring of the phenyl group, whereas the weak band near 409 nm probably may originate from the $n-\pi^{*}$ transition of the triphosphoric anion. The determination of the optical band gap (Eg), which is a pivotal parameter for describing the solid state materials, can be evaluated based on the model proposed by Tauc [62] by plotting $(\alpha h v)^{2}$ versus hv ( $\alpha$ is the absorption coefficient and hv is the energy of the incident photon where $h$ represents Planck's constant and $v$ is the frequency of vibration). The absorption edge is offered by the extrapolation of the curve until the energy axis. As shown in Fig. S7, the value of the optical band gap is $2.82 \mathrm{eV}$, which proves that the studied compound is a semiconductor and could be used for optical applications in far UV and optoelectronics [63]. The band gap between HOMO and LUMO calculated with DFT found to be $3.27 \mathrm{eV}$ is very close in value to the optical band gap $(2.82 \mathrm{eV})$.

\section{Solid state photoluminescence property}

Photoluminescence referred to as PL is a nondestructive method which is widely used to identify the luminescence property of the crystalline material. To further understand and study the optical properties of $\left(\mathrm{C}_{10} \mathrm{H}_{15} \mathrm{~N}_{2}\right)_{2} \cdot \mathrm{H}_{3} \mathrm{P}_{3} \mathrm{O}_{10}$, the photoluminescence was recorded in the solid state at room temperature over a spectral range from $360 \mathrm{~nm}$ to $470 \mathrm{~nm}$ and the spectrum is shown in Fig. S8. The emission spectrum at an excitation wavelength choosing at $\lambda_{\mathrm{ex}}=294 \mathrm{~nm}$ presents one band of luminescence located around $351 \mathrm{~nm}$. This luminescence originates from the intraligand $\pi-\pi^{*}$ of the transition of the 1-phenylpiperazinium cation. In order to determine fluorescence quantum yield of the title compound, pyrene (quantum yield $\phi_{\mathrm{r}}=0.32$ in cyclohexane) was used as a reference. The fluorescence quantum yield [64] can be calculated from the following equation [65]:

$$
\phi_{s}=\phi_{r} \frac{I_{s} A_{r} \eta_{s}^{2}}{I_{r} A_{s} \eta_{r}^{2}}
$$

Where the subscripts $s$ and $r$ stand for sample and reference, respectively. $\phi_{\mathrm{r}}$ denotes the fluorescence quantum yield of reference. I stand for the integrated area under the emission curves. A is the absorbance at a particular excitation wavelength. $\eta$ is the refractive index of the medium. The absorbance of the dye at the excitation 
wavelength was always kept $\sim 0.1$. The fluorescence quantum yield of 1-phenylpiperazinium trihydrogen triphosphate using the relative method was determined to be 0.60 . This value claims that the synthesized compound is significantly high luminescent.

\section{Viability assays}

As depicted in Fig. 9, experiments with cells were performed by measuring cell viability in the presence a wide range of concentrations of $\left(\mathrm{C}_{10} \mathrm{H}_{15} \mathrm{~N}_{2}\right)_{2} \mathrm{H}_{3} \mathrm{P}_{3} \mathrm{O}_{10}$ (from $10 \mathrm{nM}$ to $100 \mu \mathrm{M}$ ) upon incubation for 24 hours. Remarkably, no significant cytotoxic effect was observed even at high concentrations in the micro molar range and cell viability remained around $100 \%$ in all cases. These results point out that this hybrid material has no short term cytotoxicity and is biocompatible under the conditions studied, which opens the possibility for its use in biological contexts.

\section{Conclusion}

In this work, we have successfully synthesized a novel organic triphosphate. This is noteworthy since such family remained limit in comparison with the others condensed phosphates. Our founding has been characterized by using different physico-chemical techniques. The crystal structure can be described as an infinite layers of anions between them are inserted the organic cations to built, via different interactions, a three dimensional network. The Hirshfeld surface analysis reveals the percentage of intermolecular contacts of the obtained products. The geometrical parameters, collected within the framework of DFT calculations by using B3LYP methods with LANL2DZ basis set, are well correlated with the experimental results. A detailed IR studies were carried out, as can be seen, there is a good conformity between the experimental results and the theoretical ones. Moreover, NMR spectra were acquired and the results are in line with the crystallographic data. Finally, the performance of the new organic triphosphate compound in a cellular context was also tested. Remarkably, the compound was not toxic even at concentrations as high as $100 \mu \mathrm{M}$, which suggests its biocompatibility.

Overall, we hope these results could inspire future works in the development of organic phosphates and other hybrid compounds.

Abbreviations DFT, Density functional theory; ORTEP, Oak Ridge Thermal Ellipsoid Plot; ID, Distorsion indices; HOMO, Highest occupied molecular orbital; LUMO, Lowest unoccupied molecular orbital; MEP, Molecular electrostatic potential.

\section{Declarations}

Funding this work is supported by the Tunisian National Ministry of Higher Education and Scientific Research

Conflict of interest the author declares no competing interests

Availability of data and material N/A

\section{Code availability N/A}

Author contribution Y.O. synthesized the compound, discussed the results and wrote the manuscript, S.K. and N.D. performed the DFT calculations, C.T.P helped in the cytotoxicity assays, A.L.L. carried out the NMR experiments, R.M.M. reviewed the manuscript and W.S. supervised the work and corrected the manuscript.

\section{Supplementary Data}

Crystallographic data for the title compound have been deposited at the Cambridge Crystallographic Data Center as supplementary publication (CCDC 1976355). 
These data can be obtained free of charge at www.ccdc.cam.ac.uk/conts/retrieving.html (or from the Cambridge Crystallographic Data Center, 12, Union Road, Cambridge CB2 1EZ, UK; fax: +44 1223/336 033; mailto: deposit@ccdc.cam.ac.uk).

\section{References}

1. R. Rajkumar, P. Praveen Kumar (2019) Structure, crystal growth and characterization of piperazinium bis (4nitrobenzoate) dihydrate crystal for nonlinear optics and optical limiting applications. J Mol Struct 1179: 108117. https://doi.org/10.1016/j.molstruc.2018.10.085.

2. S. Chaouachi, B. Hamdi, R. Zouari (2017) Crystal structure, electrical study and dielectric behavior of a new centrosymmetric hybrid material. Synth Met 223: 122-13. https://doi.org/10.1016/j.synthmet.2016.11.030.

3. M. Hamdi, S. Karoui, A. Oueslati, S. Kamoun, F. Hlel (2018) Synthesis, crystal structure and dielectric properties of the new organic-inorganic hybrid compound $\left[\mathrm{C}_{6} \mathrm{H}_{10} \mathrm{~N}_{2}\right]_{7}\left[\mathrm{Bi}_{2} \mathrm{Cl}_{11}\right] 2.4[\mathrm{Cl}]$. J Mol Struct 1154: 516523. https://doi.org/10.1016/j. molstruc.2017.10.063.

4. K. Karoui, A. B. Rhaiem, K. Guidara (2012) Dielectric properties and relaxation behavior of [TMA] 2Zn0. 5Cu0. 5Cl 4 compound. Phys B407: 489-493. https://doi.org/10.1016/j. physb.2011.11.021.

5. A. Hachani, I. Dridi, S. Elleuch, T. Roisnel, R. Kefi (2019) Crystal structure, spectroscopic and biological study of a new inorganic-organic hybrid compound $\left[\mathrm{Cd}_{4} \mathrm{Cl}_{12}\left(\mathrm{H}_{2} \mathrm{O}\right)_{2}\right] \mathrm{n}\left(\mathrm{C}_{10} \mathrm{~N}_{4} \mathrm{H}_{28}\right)$ n. Inorg Chem Commun 100: 134-143. https://doi.org/10.1016/j.inoche.2018.12.006.

6. R. Hajji, M.A. Fersi, S. Hajji, F. Hlel, A. Ben Ahmed (2019) Hirshfeld surface analysis, vibrational spectra, optical, DFT studies and biological activities of $\left(\mathrm{C}_{7} \mathrm{H}_{12} \mathrm{~N}_{2}\right)_{2}\left[\mathrm{SnCl}_{6}\right] \mathrm{Cl}_{2}$. 1.5 $\mathrm{H}_{2} \mathrm{O}$ compound. Chem Phys Lett 722 : 160-172. https://doi.org/10.1016/j. cplett.2019.02.045.

7. M.E. Kamminga, M.C. Gélvez-Rueda, S. Maheshwari, I.S. van Droffelaar, J. Baas, G.R. Blake, F.C. Grozema, T.T.M. Palstra (2019) Electronic mobility and crystal structures of 2,5-dimethylanilinium triiodide and tin-based organic-inorganic hybrid compounds. J Solid State Chem 270: 593-600. https://doi.org/10.1016/j.jssc.2018.12.029.

8. R. Henchiri, N. Ennaceur, M. Cordier, I. Ledoux-Rak, E. Elaloui (2017) Synthesis, X-ray crystal structure and highly non-linear optical properties of inorganic-organic hybrid compound: 1,4-Diazbicyclo-octane oxonium trinitrates single crystal. J Phys Chem Solids 106: 58-64. https://doi.org/10.1016/j.jpcs.2017.02.011.

9. Y. Oueslati, S. Kansız, A. Valkonen, T. Sahbani, N. Dege, W. Smirani (2019) Synthesis, crystal structure, DFT calculations, Hirshfeld surface, vibrational and optical properties of a novel hybrid non-centrosymmetric material $\left(\mathrm{C}_{10} \mathrm{H}_{15} \mathrm{~N}_{2}\right)_{2} \mathrm{H}_{2} \mathrm{P}_{2} \mathrm{O}_{7}$. J Mol Struct 1196: 499-507. https://doi.org/10.1016/j.molstruc.2019.06.110.

10. A. Ben Rached, P. Guionneau, E. Lebraud, T. Mhiri, Z. Elaoud (2017) Structural versus electrical properties of an organic-inorganic hybrid material based on sulfate. J Phys Chem Solids 100: 25-32. https://doi.org/10.1016/j.jpcs.2016.09.006.

11. J. Nenwa, E.D. Djomo, E.N. Nfor, P.L. Djonwouo, M. Mbarki, B.P.T. Fokwa (2015) Two novel organicinorganic hybrid compounds with straight and zigzag chain alignments of $\mathrm{Cu}(\mathrm{II})$ centers: Synthesis, crystal structure, spectroscopy, thermal analysis and magnetism. Polyhedron 99: 26-33. https://doi.org/10.1016/j.poly.2015.06.023.

12. A.K. Vishwakarma, R. Kumari, P.S. Ghalsasi, N. Arulsamy (2017) Crystal structure, thermochromic and magnetic properties of organic-inorganic hybrid compound: $\left(\mathrm{C}_{7} \mathrm{H}_{7} \mathrm{~N}_{2} \mathrm{~S}\right)_{2} \mathrm{CuCl}_{4}$. J Mol Struct 1141: 93-98. https://doi.org/10.1016/j. molstruc.2017.03.076. 
13. M.-H. Teiten, M. Dicato, M. Diederich (2014) Hybrid Curcumin Compounds: A New Strategy for Cancer Treatment. Molecules 19: 20839-20863. https://doi.org/10.3390/molecules 191220839.

14. E. Ruiz-Hitzky, P. Aranda, M. Darder, G. Rytwo (2010) Hybrid materials based on clays for environmental and biomedical applications. J Mater Chem 20: 9306-9321. https://doi.org/10.1039/C0JM00432D.

15. W. Smirani, C.B. Nasr, M. Rzaigui (2004) Synthesis and crystal structure of a new o-ethylphenylammonium triphosphate $\quad\left[2-\mathrm{C}_{2} \mathrm{H}_{5} \mathrm{C}_{6} \mathrm{H}_{4} \mathrm{NH}_{3}\right] 3 \mathrm{H}_{2} \mathrm{P}_{3} \mathrm{O}_{10}$. Mater $\quad$ Res $\quad$ Bull 39: 1103-1111. https://doi.org/10.1016/j.materresbull.2004.02.013.

16. W. Smirani, C.B. Nasr, M. Rzaigui (2004) Synthesis and Structure Characterization of Piperazine1,4-diium Triphosphate. Phosphorus Sulfur Silicon Relat Elem 179: 2195-2204. https://doi.org/10.1080/10426500490475003.

17. W. Sta, R. Mohamed (2005) Crystal structure of tris(3,5-diinethoxyanilinium) dihydrogentriphosphate, $\left[\left(\mathrm{CH}_{3} \mathrm{O}\right)_{2}\left(\mathrm{C}_{6} \mathrm{H}_{3} \mathrm{NH}_{3}\right)\right]_{3}\left[\mathrm{H}_{2} \mathrm{P}_{3} \mathrm{O}_{10}\right]$. Z Kristallogr NCS 220: 250-252. https://doi.org/10.1524/ncrs.2005.220.14.260. 18. W. Sta, R. Mohamed (2005) Structural Characterization of a New Organic Triphosphate, [4$\left.\left(\mathrm{OCH}_{3}\right) \mathrm{C}_{6} \mathrm{H}_{4} \mathrm{CH}_{2} \mathrm{NH}_{3}\right]_{4} \mathrm{H}_{2} \mathrm{P}_{3} \mathrm{O}_{10} \mathrm{H}_{4} \mathrm{P}_{3} \mathrm{O}_{10}$. Analytical Sciences X-ray Structure Analysis Online 21: x109-x110. https://doi.org/10.2116/analscix.21.x109.

19. W. Smirani (2007) Crystal Structure and Spectroscopic Studies of $\left[2,6-\left(\mathrm{C}_{2} \mathrm{H}_{5}\right)_{2} \mathrm{C}_{6} \mathrm{H}_{3} \mathrm{NH}_{3}\right]_{2} \mathrm{H}_{3} \mathrm{P}_{3} \mathrm{O}_{10}$. Phosphorus Sulfur Silicon Relat Elem 182: 1727-1737. https://doi.org/10.1080/10426500701313904.

20. S. Souissi, W. Smirani, C.B. Nasr, M. Rzaigui (2007) Structural and physicochemical studies of [2,3$\left.\left(\mathrm{CH}_{3}\right)_{2} \mathrm{C}_{6} \mathrm{H}_{3} \mathrm{NH}_{3}\right]_{4} \mathrm{HP}_{3} \mathrm{O}_{10} \cdot 2 \mathrm{H}_{2} \mathrm{O}$. Phosphorus Sulfur Silicon Relat Elem 182: 2731-2743. https://doi.org/10.1080/10426500701519336.

21. J. Mechergui, W. Belam, R. Mohamed (2007) Crystal structure of 1-(2,3-dimethylphenyl) piperazinium dihydrogentriphosphate trihydrate, $\left[\mathrm{C}_{12} \mathrm{H}_{19} \mathrm{~N} 2\right]_{3}\left[\mathrm{H}_{2} \mathrm{P}_{3} \mathrm{O}_{10}\right] . \quad 3 \mathrm{H}_{2} \mathrm{O} . \quad \mathrm{Z}$ Kristallogr NCS 222: 409-411. https://doi.org/10.1524/ncrs.2007.0174.

22. S. Belghith, L.B. Hamada, A. Jouini (2013) Crystal Structure and Physicochemical Properties of a New 4,4'Diammoniumdiphenylether Triphosphate $\left[\mathrm{C}_{12} \mathrm{H}_{14} \mathrm{~N}_{2} \mathrm{O}\right]_{2} \mathrm{HP}_{3} \mathrm{O}_{10} .2 \mathrm{H}_{2} \mathrm{O}$. J Inorg Organomet Polym Mater 23: 779 783. https://doi.org/10.1007/s10904-013-9831-z.

23. A. Ryckebusch, M.-A. Debreu-Fontaine, E. Mouray, P. Grellier, C. Sergheraert, P. Melnyk (2005) Synthesis and antimalarial evaluation of new N1-(7-chloro-4-quinolyl)-1,4-bis(3-aminopropyl)piperazine derivatives. Bioorg Med Chem Lett 15: 297-302. http://doi.org/10.1016/j.bmcl.2004.10.080.

24. A. Ryckebusch, R. Deprez-Poulain, M.-A. Debreu-Fontaine, R. Vandaele, E. Mouray, P. Grellier, C. Sergheraert (2003) Synthesis and antimalarial evaluation of new 1,4-bis(3-aminopropyl)piperazine derivatives. Bioorg Med Chem Lett 13: 3783-3787. https://doi.org/10.1016/j. bmcl.2003.07.008.

25. S.-F. Wang, Y. Yin, F. Qiao, X. Wu, S. Sha, L. Zhang, H.-L. Zhu (2014) Synthesis, molecular docking and biological evaluation of coumarin derivatives containing piperazine skeleton as potential antibacterial agents. Bioorg Med Chem 22: 2409-2415. https://doi.org/10.1016/j.bmc.2014.09.048.

26. J.P. Yevich, J.S. New, D.W. Smith, W.G. Lobeck, J.D. Catt, J.L. Minielli, M.S. Eison, D.P. Taylor, L.A. Riblet, D.L. Temple (1986) Synthesis and biological evaluation of 1-(1,2-benzisothiazol-3-yl) and (1,2benzisoxazol-3-yl) piperazine derivatives as potential antipsychotic agents. J Med Chem 29: 359-369. https://doi.org/10.1021/jm00153a010. 
27. S.H. Bhosale, A.M. Kanhed, R.C. Dash, M.R. Suryawanshi, K.R. Mahadik (2014) Design, synthesis, pharmacological evaluation and computational studies of 1-(biphenyl-4-yl)-2-[4-(substituted phenyl)-piperazin1-yl]ethanones as potential antipsychotics. Eur J Med Chem 74: 358-365. https://doi.org/10.1016/j.ejmech.2013.12.043.

28. A. Bali, S. Malhotra, H. Dhir, A. Kumar, A. Sharma (2009) Synthesis and evaluation of 1(quinoliloxypropyl)-4-aryl piperazines for atypical antipsychotic effect. Bioorg Med Chem Lett 19: 3041-3044. http://doi.org/10.1016/j.bmcl.2009.04.019.

29. H. Suryavanshi, M. Rathore (2017) Synthesis and biological activities of piperazine derivatives as antimicrobial and antifungal agents. Org Commun 10: 228-238. http://doi.org/10.25135/acg.oc.23.17.05.026.

30. S. Koparde, K. M. Hosamani, V. Kulkarni, S. D. Joshi (2018) Synthesis of coumarin-piperazine derivatives as potent anti-microbial and anti-inflammatory agents, and molecular docking studies. Chem Data Collect 15-16: 197-206. https://doi.org/10.1016/j.cdc.2018.06.001.

31. G. Sheldrick (2015) SHELXT - Integrated space-group and crystal-structure determination. Acta Cryst A71: 3-8. https://doi.org/10.1107/S2053273314026370.

32. G.M. Sheldrick (2015) Crystal structure refinement with SHELXL. Acta Cryst C71: 3-8. https://doi.org/10.1107/S2053229614024218.

33. K. Brandenburg (1998) DIAMOND Version 2.0

34. S. Wolff, D. Grimwood, J. McKinnon, M. Turner, D. Jayatilaka, M. Spackman (2012) Crystal explorer. The University of Western Australia Perth, Australia

35. M.J. Frisch, G.W. Trucks, H.B. Schlegel, G.E. Scuseria, M.A. Robb, J.R. Cheeseman, J.A. Montgomery Jr., T. Vreven, K.N. Kudin, J.C. Burant, J.M. Millam, S.S. Iyengar, J. Tomasi, V. Barone, B. Mennucci, M. Cossi, G. Scalmani, N. Rega, G.A. Petersson, H. Nakatsuji, M. Hada, M. Ehara, K. Toyota, R. Fukuda, J. Hasegawa, M. Ishida, T. Nakajima, Y. Honda, O. Kitao, H. Nakai, M. Klene, X. Li, J.E. Knox, H.P. Hratchian, J.B. Cross, V. Bakken, C. Adamo, J. Jaramillo, R. Gomperts, R.E. Stratmann, O. Yazyev, A.J. Austin, R. Cammi, C. Pomelli, J.W. Ochterski, P.Y. Ayala, K. Morokuma, G.A. Voth, P. Salvador, J.J. Dannenberg, V.G. Zakrzewski, S. Dapprich, A.D. Daniels, M.C. Strain, O. Farkas, D.K. Malick, A.D. Rabuck, K. Raghavachari, J.B. Foresman, J.V. Ortiz, Q. Cui, A.G. Baboul, S. Clifford, J. Cioslowski, B.B. Stefanov, G. Liu, A. Liashenko, P. Piskorz, I. Komaromi, R.L. Martin, D.J. Fox, T. Keith, M.A. Al- Laham, C.Y. Peng, A. Nanayakkara, M. Challacombe,

P.M.W. Gill, B. Johnson, W. Chen, M.W. Wong, C. Gonzalez, J.A. Pople (2004) Gaussian 03, Revision E.01, Gaussian, Inc., Wallingford, CT

36. R. Dennington II, T. Keith, J. Millam (2007) Gauss View, Version 4.1.2, Semichem Inc., Shawnee Mission, $\mathrm{KS}$

37. Ö. Tamer, D. Avcı, Y. Atalay (2016) Synthesis, X-Ray crystal structure, photophysical characterization and nonlinear optical properties of the unique manganese complex with picolinate and 1,10 phenantroline: toward the designing of new high NLO response crystal. J Phys Chem Solids 99: 124-133. https://doi.org/10.1016/j.jpcs.2016.08.013.

38. W. Baur (1974) The geometry of polyhedral distortions. Predictive relationships for the phosphate group. Acta Cryst B30: 1195-1215. https://doi.org/10.1107/S0567740874004560.

39. D. Cremer, J.A. Pople (1975) General definition of ring puckering coordinates. J Am Chem Soc 97: 13541358. https://doi.org/10.1021/ja00839a011. 
40. J.J. McKinnon, M.A. Spackman, A.S. Mitchell (2004) Novel tools for visualizing and exploring intermolecular interactions in molecular crystals. Acta Cryst B60: 627-668. https://doi.org/10.1107/S0108768104020300 41. M.A. Spackman, D. Jayatilaka (2009) Hirshfeld surface analysis. Cryst Eng Comm 11: 19-32. https://doi.org/10.1039/B818330A.

42. M. A. Spackman, P.G. Byrom (1997) A novel definition of a molecule in a crystal. Chem Phys Lett 267: 215-220. https://doi.org/10.1016/S0009-2614(97)00100-0.

43. R. Ilmi, S. Kansiz, N. Dege, M. S. Khan (2019) Synthesis, structure, Hirshfeld surface analysis and photophysical studies of red emitting europium acetylacetonate complex incorporating a phenanthroline derivative. J Photochem Photobiol A 377: 268-281. https://doi.org/10.1016/j.jphotochem.2019.03.036.

44. S. Kansiz, N. Dege, Y. Topcu, Y. Atalay, S. V. Gaidai (2018) Crystal structure and Hirshfeld surface analysis of (succinato $\kappa \mathrm{O})\left[\mathrm{N}, \mathrm{N}, \mathrm{N}^{\prime}, \mathrm{N}^{\prime}\right.$ tetra-kis-(2 hy-dr-oxy-eth-yl)ethyl-enedi-amine $\left.\kappa 5 \mathrm{O}, \mathrm{N}, \mathrm{N}^{\prime}, \mathrm{O}^{\prime}, \mathrm{O}^{\prime \prime}\right]$ nickel(II) tetra-hydrate. Acta Crystallogr E74: 1700-1704. https://doi.org/10.1107/S2056989018015359.

45. S. Kansız, A. Tolan, H. İçbudak, N. Dege (2019) Synthesis, crystallographic structure, theoretical calculations, spectral and thermal properties of trans-diaquabis(trans-4-aminoantipyrine)cobalt(II) acesulfamate. J Mol Struct 1190: 102-115. https://doi.org/10.1016/j.molstruc.2019.04.058.

46. W. Guerrab, I.-M. Chung, S. Kansiz, J. T. Mague, N. Dege, J. Taoufik, R. Salghi, I. H. Ali, M. I. Khan, H. Lgaz, Y. Ramli (2019) Synthesis, structural and molecular characterization of 2,2-diphenyl-2H,3H,5H,6H,7Himidazo[2,1-b][1,3]thiazin-3-one. J Mol Struct 1197: 369-376. https://doi.org/10.1016/j.molstruc.2019.07.081.

47. M. Gabelica-Robert, P. Tarte (1982) Infrared spectrum of crystalline and glassy pyrophosphates : preservation of the pyrophosphate group in the glassy structure. J Mol Struct 79: 251-254. https://doi.org/10.1016/0022-2860(82)85061-8.

48. B.C. Cornilson (1984) Solid state vibrational spectra of calcium pyrophosphate dihydrate. J Mol Struct 117: 1-9. https://doi.org/10.1016/0022-2860(84)87237-3.

49. C. Sivakumar, V. Balachandran, B. Narayana, V.V. Salian, B. Revathi, N. Shanmugapriya, K. Vanasundari (2021) Molecular spectroscopic investigation, quantum chemical, molecular docking and biological evaluation of 2-(4-Chlorophenyl)-1-[3-(4-chlorophenyl)-5-[4-(propan-2-yl) phenyl-3, 5-dihydro-1H-pyrazole-yl] ethanone. J Mol Struct 1224: 129010. https://doi.org/10.1016/j.molstruc.2020.129010.

50. D. Shoba, M. Karabacak, S. Periandy, S. Ramalingam (2011) FT-IR and FT-Raman vibrational analysis, ab initio HF and DFT simulations of isocyanic acid 1-naphthyl ester. Spectrochim Acta Part A 81: 504-518. https://doi.org/10.1016/j.saa.2011.06.044.

51. S. Kansiz, N. Dege (2018) Synthesis, crystallographic structure, DFT calculations and Hirshfeld surface analysis of a fumarate bridged $\mathrm{Co}(\mathrm{II})$ coordination polymer. J Mol Struct 1173: 42-51. https://doi.org/10.1016/j.molstruc.2018.06.071.

52. C.C. Ersanli, G.K. Kantar, S. Şaşmaz (2017) Crystallographic, spectroscopic (FTIR and NMR) and quantum computational calculation studies on bis(2-methoxy-4-((E)-prop-1-enyl)phenyl)oxalate. J Mol Struct 1143: 318327. https://doi.org/10.1016/j.molstruc.2017.04.032.

53. I. Tankov, R. Yankova (2019) Hirshfeld surface, DFT vibrational (FT-IR) and electronic (UV-vis) studies on 4-amino-1H-1,2,4-triazolium nitrate. J Mol Struct $\quad$ 1179: 581-592. https://doi.org/10.1016/j.molstruc.2018.11.050. 
54. R.G. Pearson (1988) Absolute electronegativity and hardness: application to inorganic chemistry. Inorg Chem 27: 734-740. https://doi.org/10.1021/ic00277a030.

55. V. Sastri, J. Perumareddi (1997) Molecular Orbital Theoretical Studies of Some Organic Corrosion Inhibitors. Corrosion 53: 617-622. https://doi.org/10.5006/1.3290294.

56. F. Şen, S. Kansiz, I. Uçar (2017) A one-dimensional copper(II) coordination polymer incorporating succinate and N,N-di-ethyl-ethyl-ene-diamine ligands: crystallographic analysis, vibrational and surface features, and DFT analysis. Acta Crystallogr C73: 517-524. https://doi.org/10.1107/S2053229617008452.

57. Z. Demircioğlu, C.C. Ersanli, G.K. Kantar, S. Şaşmaz (2019) Spectroscopic, Hirshfeld surface, X-ray diffraction methodologies and local \& global chemical activity calculations of 5-(2-methoxy-4-(prop-1-en-1yl)phenoxy)pyrazine-2,3-dicarbonitrile. $\quad$ J $\quad$ Mol $\quad$ Struct $\quad 1181: \quad$ 25-37. https://doi.org/10.1016/j.molstruc.2018.12.072.

58. I. Tankov, R. Yankova (2019) Mechanistic investigation of molecular geometry, intermolecular interactions and spectroscopic properties of pyridinium nitrate. Spectrochim Acta A 219: 53-67. https://doi.org/10.1016/j.saa.2019.04.027.

59. V. Gopi, S. Subbiahraj, K. Chemmanghattu, P. C. Ramamurthy (2020) 2,3-di(2-furyl) quinoxaline bearing 3 -ethyl rhodanine and 1,3 indandione based heteroaromatic conjugated T-shaped push -pull chromophores: Design, synthesis, photophysical and non-linear optical investigations. Dyes Pigments 173: 107887. https://doi.org/10.1016/j.dyepig.2019.107887.

60. L. Khedhiri, A. Hamdi, S. Soudani, W. Kaminsky, F. Lefebvre, C. Jelsch, M. Wojtaś, C. Ben Nasr (2018) Crystal structure, Hirshfeld surface analysis, thermal behavior and spectroscopic investigations of a new organic cyclohexaphosphate, $\quad\left(\mathrm{C}_{10} \mathrm{H}_{15} \mathrm{~N}_{2}\right)_{4}(\mathrm{Li})_{2}\left(\mathrm{P}_{6} \mathrm{O}_{18}\right)\left(\mathrm{H}_{2} \mathrm{O}\right)_{6} . \quad \mathrm{J} \quad$ Mol $\quad$ Struct $\quad 1171: \quad 429-437$. https://doi.org/10.1016/j.molstruc.2018.06.015.

61. M. Essid, Z. Aloui (2019) Synthesis, Hirshfeld surface analysis and physicochemical studies of noncentrosymmetric semi-organic compound: $\left[\mathrm{C}_{10} \mathrm{H}_{15} \mathrm{~N}_{2}\right]\left(\mathrm{H}_{2} \mathrm{PO}_{4}\right)$. Chem Data Collect 24: 100285 . https://doi.org/10.1016/j.cdc.2019.100285.

62. J. Tauc (1968) Optical properties and electronic structure of amorphous Ge and Si. Mater Res Bull 3: 37-46. https://doi.org/10.1016/0025-5408(68)90023-8.

63. S. Franklin, T. Balasubramanian, K. Nehru, Y. Kim (2009) Crystal structure, conformation, vibration and optical band gap analysis of bis [rac-propranolol nitrate]. J Mol Struct 927: 121-125. https://doi.org/10.1016/j.molstruc.2009.03.003.

64. M. G. Lagorio (2020) Determination of Fluorescence Quantum Yields in Scattering Media. Methods Appl Fluoresc 8: 043001. https://doi.org/10.1088/2050-6120/aba69c.

65. C. Würth, M. Grabolle, J. Pauli, M. Spieles (2013) Relative and absolute determination of fluorescence quantum yields of transparent samples. $U$ Resch-Genger Nat Protoc 8: 1535-1550. https://doi.org/10.1038nprot.2013.087. 
Figures

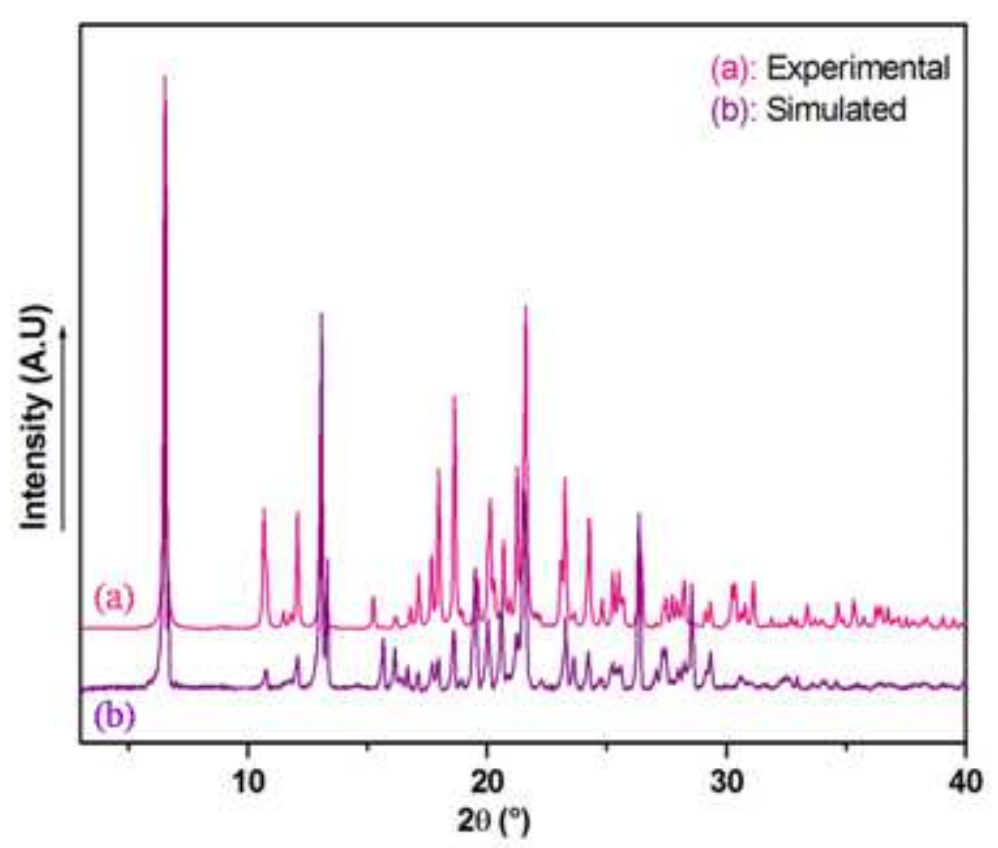

\section{Figure 1}

Experimental and simulated powder XRD patterns of the prepared compound (C10H15N2)2H3P3O10.

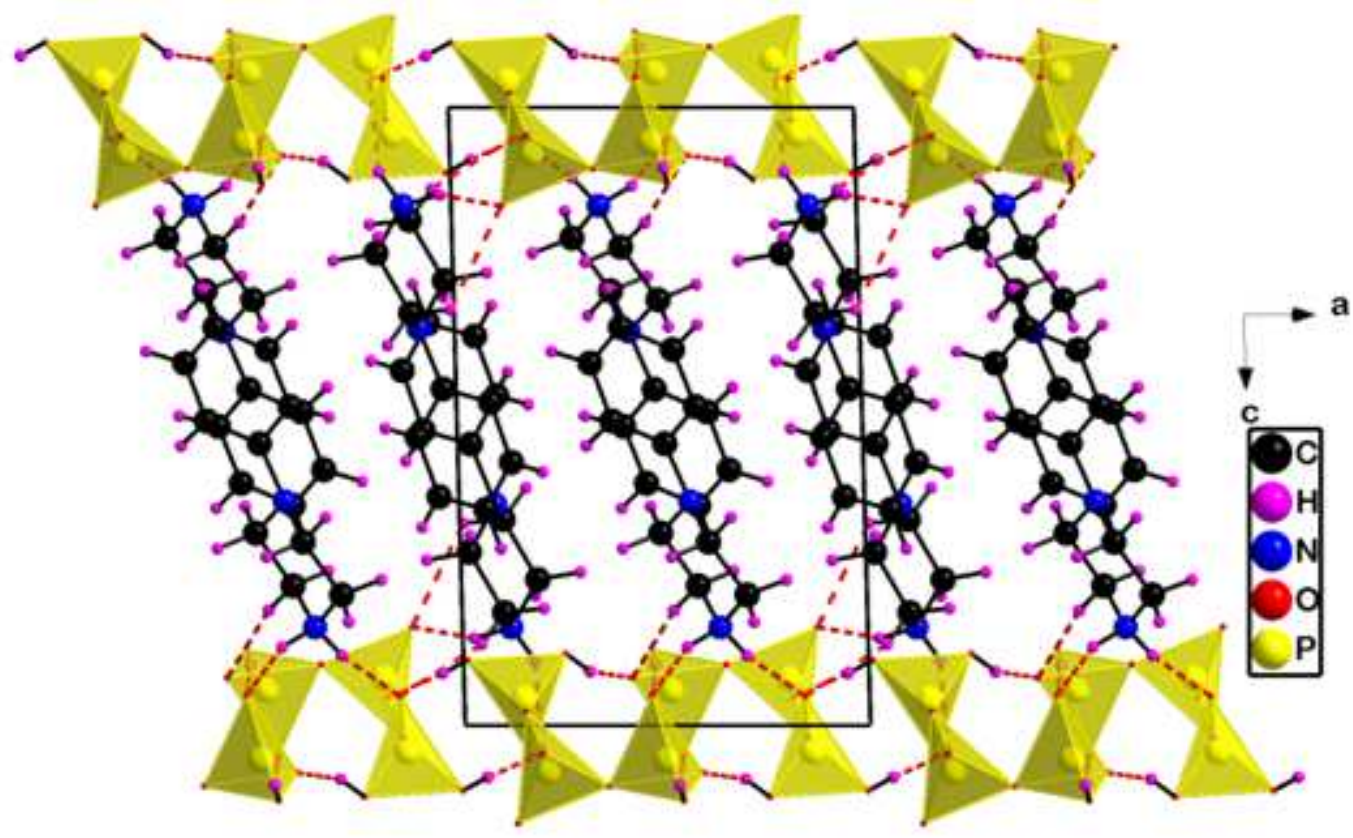

Figure 2

Projection of the crystal structure of $(\mathrm{C} 10 \mathrm{H} 15 \mathrm{~N} 2) 2 \mathrm{H} 3 \mathrm{P} 3010$ in the (ac) plane. 


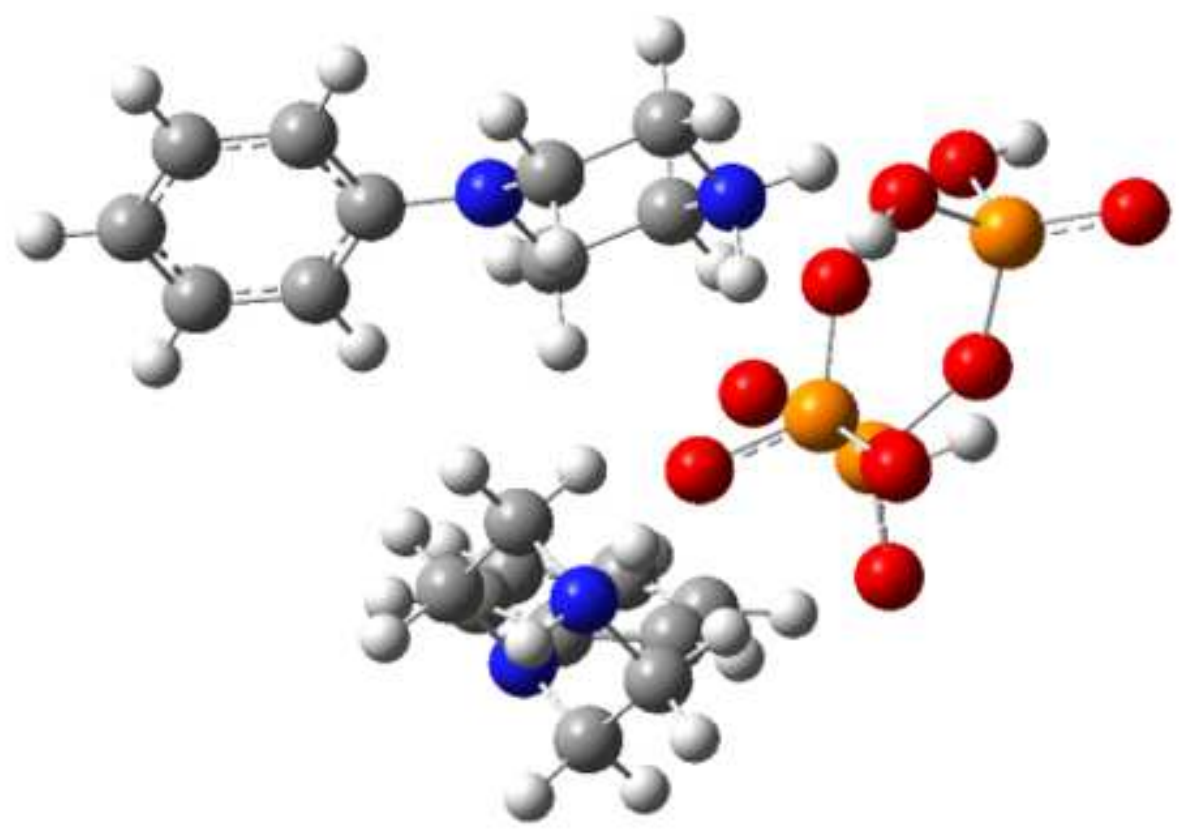

Figure 3

The optimized geometric structure of $(\mathrm{C} 10 \mathrm{H} 15 \mathrm{~N} 2) 2 \mathrm{H} 3 \mathrm{P} 3010$.

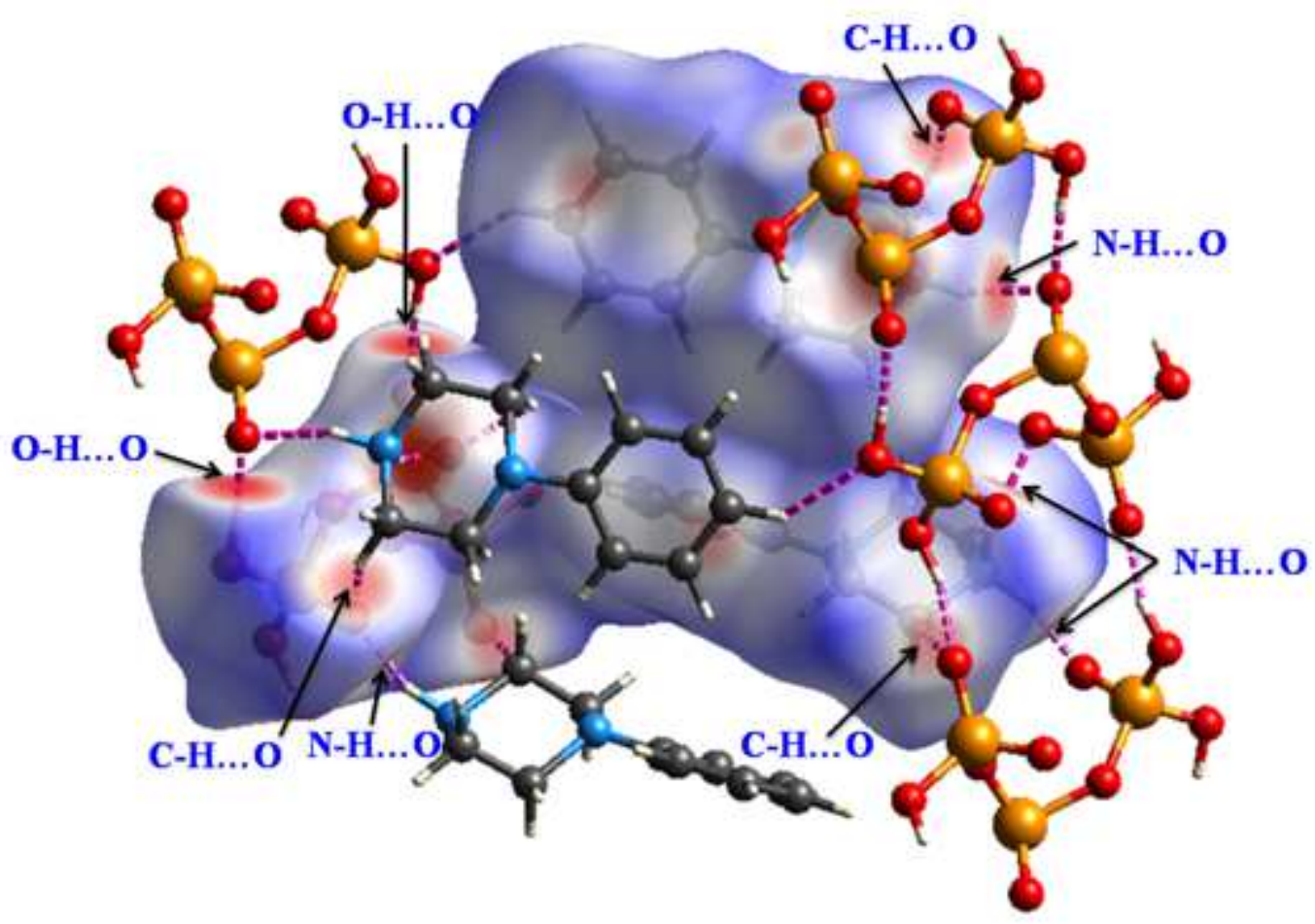

Figure 4

Hirshfeld surface of (C10H15N2)2H3P3010 mapped on the dnorm. 

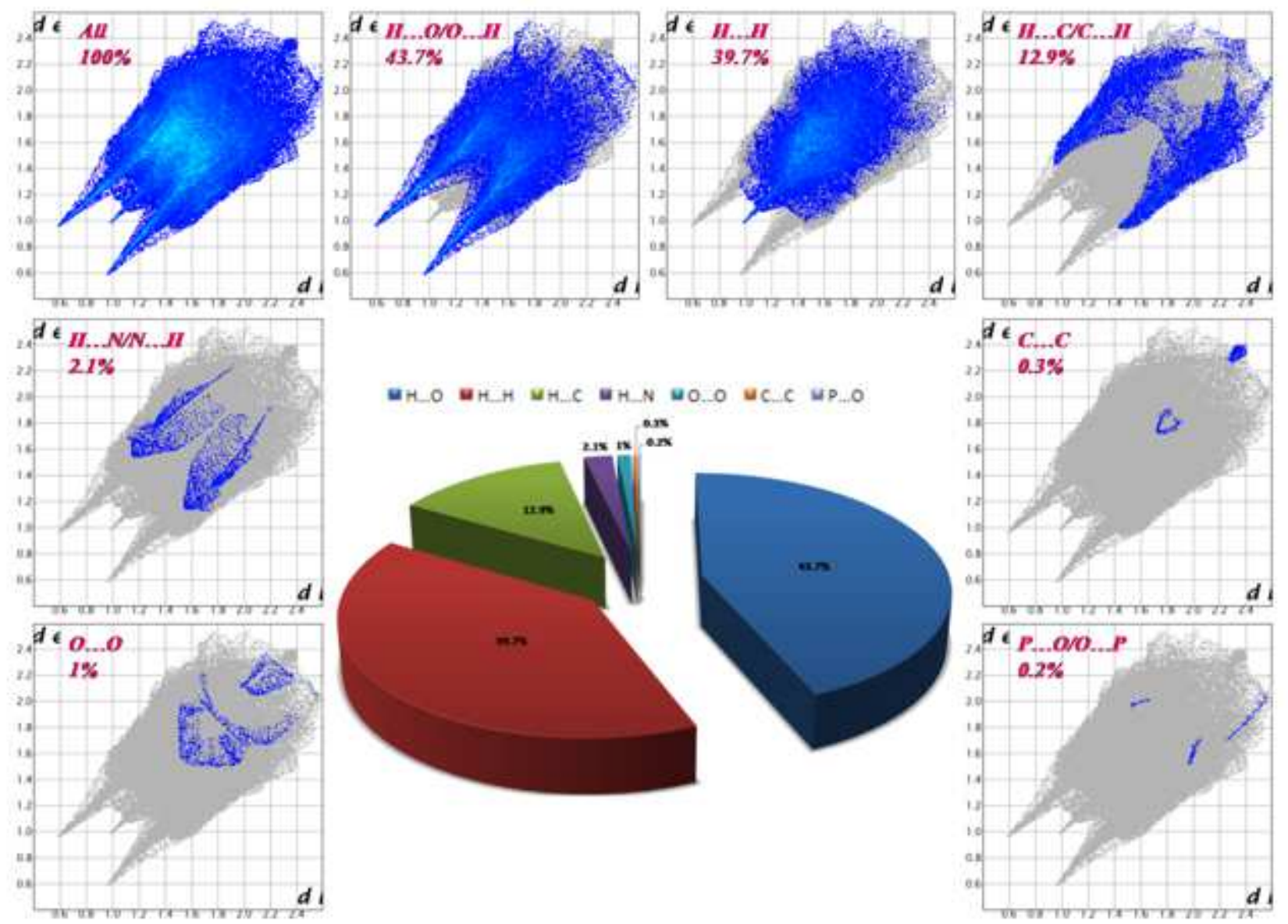

Figure 5

The view of the 2D fingerprint plots with a dnorm for (a) the sum of the contacts contributing to the Hirshfeld surface, (b) O...H/H...O (43.7\%), (c) H...H (39.7\%) and (d) C...H/H...C (12.9\%) contacts in (C10H15N2)2H3P3O10.

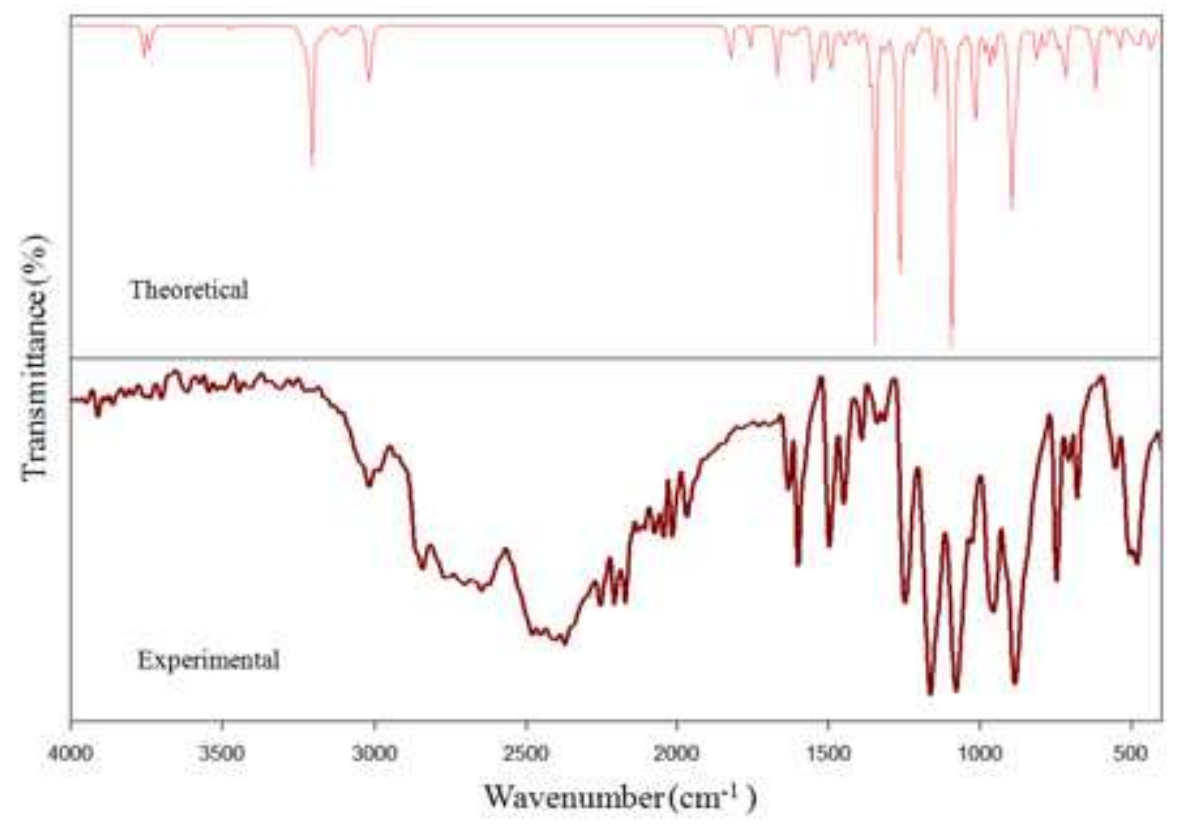


Figure 6

Simulated IR spectra of (C10H15N2)2H3P3010 computed at B3LYP/ LANL2DZ basis set (red). FTIR spectrum (blue).

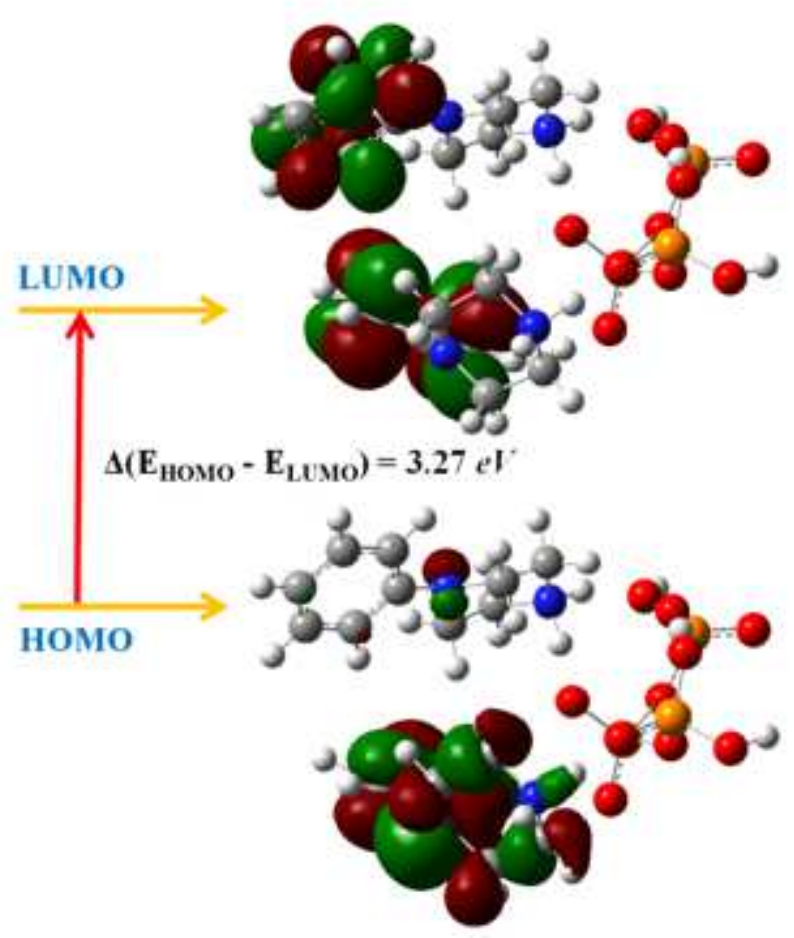

Figure 7

The electron distribution of the HOMO and LUMO energy levels.

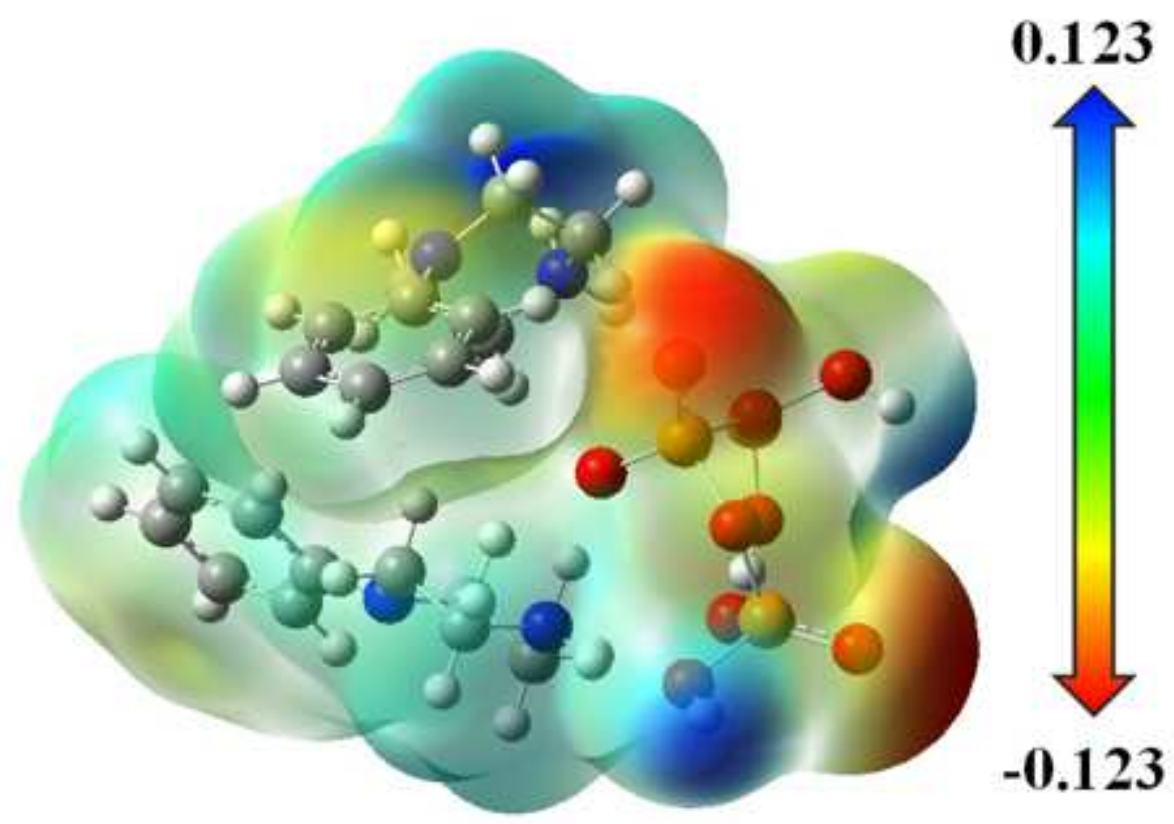


Figure 8

The total electron density three-dimensional surface mapped for the compound with the electrostatic potential calculated at the B3LYP/LANL2DZ level.

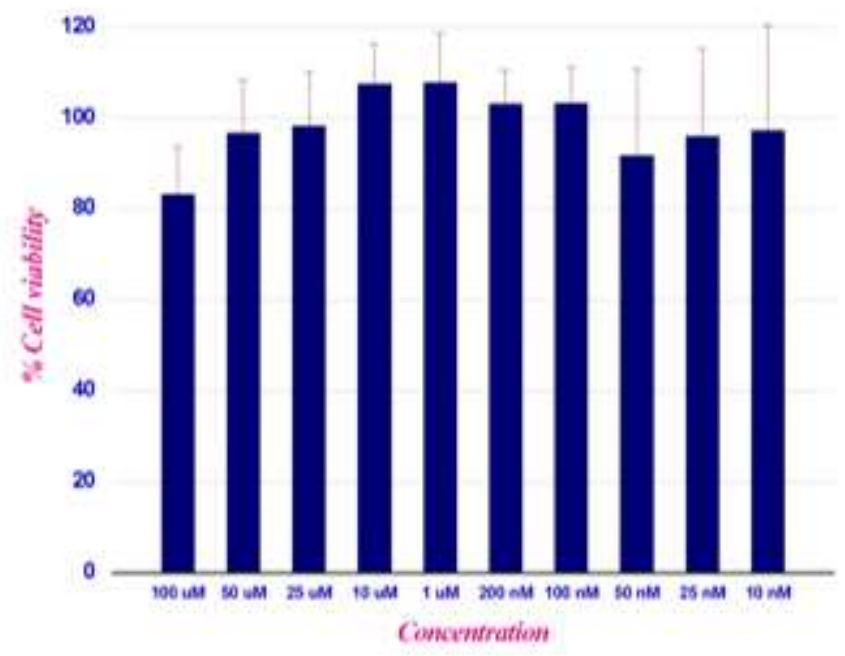

Figure 9

Cell viability determined in RAW 264.7 mouse macrophages after $(\mathrm{C} 10 \mathrm{H} 15 \mathrm{~N} 2) 2 \mathrm{H} 3 \mathrm{P} 3010$ treatment at different concentrations for $24 \mathrm{~h}$.

\section{Supplementary Files}

This is a list of supplementary files associated with this preprint. Click to download.

- GRAPHICALABSTRACT.docx

- SupportingInformation.docx 